\title{
ПРЕОБРАЗОВАНИЕ ЭФФУЗИВНЫХ ПОРОД ПОД ВОЗДЕЙСТВИЕМ КИСЛОТНОГО ВЫЩЕЛАЧИВАНИЯ ПОВЕРХНОСТНЫМИ ТЕРМАЛЬНЫМИ ВОДАМИ (ГЕОТЕРМАЛЬНАЯ СИСТЕМА БАРАНСКОГО, О-В ИТУРУП)
}

\author{
(C) 2014 г. В. М. Ладыгин, Ю. В. Фролова, С. Н. Рычагов 1 \\ Геологический факультет МГУ им. М.В. Ломоносова \\ 119234 Москва, Ленинские горы, e-mail: skalka@geol.msu.ru \\ ${ }^{1}$ Институт вулканологии и сейсмологии ДВО РАН \\ 683006 Петропавловск-Камчатский, бульвар Пийnа, 9, e-mail: rychsn@kscnet.ru \\ Поступила в редакцию 20.02.2012 г.
}

\begin{abstract}
Рассмотрены закономерности преобразования эффузивных пород вулкана Баранского (центральная часть о-ва Итуруп) под влиянием сульфатно-хлоридных кислых и ультракислых вод термального ручья Кипящая Речка. Получены данные об изменении их химического и минерального состава, структурных особенностей, пористости и петрофизических свойств. Описаны динамика процесса выщелачивания и стадии преобразования пород в проточной кислой (ультракислой) геотермальной среде. Отмечается, что механизм сернокислотного выщелачивания пород на дневной поверхности может быть во многом аналогичен процессу образования вторичных кварцитов (монокварцитов) в зонах восходящих потоков кислых газов над малыми интрузиями габбродиоритов - диоритов.
\end{abstract}

DOI: $10.7868 / \mathrm{S} 0203030614010039$

\section{ВВЕДЕНИЕ}

В пределах современных гидротермальных (геотермальных) систем областей четвертичного вулканизма происходит активное преобразование горных пород. Под воздействием термальных вод первичные компоненты вулканических пород - стекло, полевые шпаты, темноцветные минералы выщелачиваются и замещаются вторичными минералами, более устойчивыми в условиях изменившихся температуры, давления и состава гидротермального раствора. Одним из гидротермально-метасоматических процессов является сернокислотное выщелачивание пород, которое обычно происходит в приповерхностной зоне высокотемпературных гидротермальных систем под влиянием восходящих кислых (ультракислых) сульфатных и сульфатно-хлоридных вод с температурой $\leq 100^{\circ} \mathrm{C}$. Сернокислотное выщелачивание и образование пород фации опалитов - явление широко распространенное и хорошо изученное с точки зрения понимания минеральных преобразований [Ерощев-Шак, 1992; Карпов, 1991; Коржинский, 1955; Коробов, 1994; Лебедев, 1979; Метасоматизм ..., 1998; Набоко и др., 1965; Русинов, 1989; Reyes, 1990]. Известно, что основными новообразованиями зоны сернокислотного выщелачивания являются минералы кремнезема (опал, тридимит, кристобалит, халцедон, кварц), сульфаты (гипс, барит, алунит, ярозит), глинистые минералы (каолинит, галлуазит), самород- ная сера, гидрооксиды железа и алюминия. Но обычно отмечаются конечные продукты этого процесса в целом или для каждой стадии сернокислотного выщелачивания, тогда как динамика изменения породы (вынос/привнос химических элементов, этапы формирования минерального состава, пористости, структуры порового пространства и петрофизических свойств пород) изучена недостаточно.

В основу настоящей работы положены результаты исследования аллювия ручья Кипящая Речка, берущего начало на склоне действующего андезитового вулкана Баранского (центральная часть о-ва Итуруп) и пересекающего геотермальную систему с одноименным названием. В ходе комплексных геолого-геохимических исследований системы [Коробов, 1994; Ладыгин, Рычагов, 1995; Рычагов, 1993; Рычагов и др., 1993] авторы обратили внимание на формирование четко выраженной зональности в валунах и гальке аллювия термального ручья в виде желтых, светло-серых и более темных концентрических полос мощностью от миллиметров до нескольких сантиметров. Было установлено, что это явление характерно только для образцов пород, находящихся в проточной кислой среде (в ручье ниже очагов разгрузки источников с ультракислыми сульфатными и сульфатно-хлоридными термальными водами - Голубые озера и Кипящие). Таким образом, природа сама провела эксперимент, который 
позволяет решать ряд вопросов, традиционно имеющих большое научное и практическое значение при изучении каждой геотермальной системы: каковы характер и направленность гидротермальных изменений пород в зонах активной циркуляции гидротермальных растворов, можно ли количественно оценить интенсивность преобразования пород в проточной кислой среде, каковы механизмы формирования метасоматической зональности в таких условиях, возможна ли оценка скорости преобразования пород в естественном залегании. Сразу отметим, что последний вопрос остался на стадии постановки проблемы и в статье не рассматривается.

Цель настоящей работы состояла в выявлении закономерностей изменения состава, структуры и свойств эффузивных пород под влиянием проточных кислых (до ультракислых) термальных вод; исследовании механизмов формирования метасоматической зональности при сернокислотном выщелачивании горных пород.

\section{ГЕОЛОГИЧЕСКИЕ УСЛОВИЯ}

В центральной части острова Итуруп на Южных Курилах находится действующий андезитовый вулкан Баранского, входящий в структуру вулканического хребта Иван Грозный. К северозападному склону и подножию вулкана приурочена одноименная гидротермальная система, в центральной части которой выделено геотермальное месторождение Океанское [Пчелкин, 1988]. Система является высокотемпературной и находится на прогрессивной галоидно-сульфатноуглекислотной стадии развития [Рычагов, 1993]. Основание геологического разреза сложено псефо-псаммитовыми и агломератовыми туфами и лавами андезитов парусной свиты неогенового возраста. Их прорывают диориты - габбро-диориты; предполагается, что субвулканические тела этих пород связаны с глубинным магматическим очагом и обеспечивают тепловое питание гидротермальной системы. Водовмещающая толща представлена мелко-грубообломочными туффитами, туфами и лавами андезитов лебединской свиты нижнечетвертичного возраста, залегающими на породах парусной свиты без видимого углового несогласия. Эти породы хорошо проницаемы для термальных вод, под действием которых сформировалась гидротермально-метасоматическая зональность, типичная для геотермальных систем прогрессивного этапа развития. В разрезе снизу вверх сформированы: вторичные кварциты (гранат-кварцевая, монокварцевая и мусковитсерицит-кварцевая минеральные ассоциации), среднетемпературные пропилиты (эпидот-кварцкальцит-хлоритовая ассоциация), низкотемпературные пропилиты (вайракит-кальцитовая, ломонтит-кварцевая, пренит-кальцитовая, кварц- хлорит-кальцитовая ассоциации), аргиллизиты (кварц-хлорит-смектиты) и опалиты [Коробов, 1994; Рычагов и др., 1993]. Зоны отличаются характером переработки материнских пород и петрофизическими свойствами [Ладыгин, Рычагов, 1995; Фролова и др., 1999; Ladygin et al., 2000]. Опалитовая зона является приповерхностной и образована под действием сернокислотного выщелачивания, мощность ее составляет десятки метров, а в зонах разломов достигает 200 м.

Наиболее интенсивные преобразования пород до гидротермальных глин и моноопалитов - происходят на термальных полях вокруг кипящих источников, грязевых котлов, паровых струй, на парящих площадках. Несколько групп источников термальных вод дают начало ручью Кипящая Речка. Ручей имеет длину 1.4 км, течет в неглубокой долине, выполненной грубообломочными вулканогенными отложениями, и впадает в р. Серную. Основные особенности гидрохимии ручья определяются водой источников Кипящие и Голубые озера. Температура воды источников составляет 81$95^{\circ} \mathrm{C}$ (до $\left.98^{\circ} \mathrm{C}\right)$, общая минерализация от 1.9 до 5.8 г/л, рН от 0.7 до 1.7, Eh от +200 до +590 мВ, состав сульфатный и сульфатно-хлоридный с высоким содержанием $\mathrm{Na}$ и К [Знаменский, Никитина, 1985]. Источники бурлят от выходов свободных газов: сероводорода, метана, водорода, углекислого газа и азота; флюоресцируют от большого количества в воде самородной мелкодисперсной серы. Состав воды в ручье формируется в результате смешения термальных вод этих и расположенных ниже по течению других групп источников (Водопадные, Котел, Нижние, Устьевые, Скрытые) с холодными метеорными водами. Воды ручья остаются кислыми вследствие большого суммарного дебита источников (ориентировочно $\geq 100$ л/с). На устье ручья его дебит составляет 200 л/с, температура воды $30-32^{\circ} \mathrm{C}$. С водой ручья ежесуточно выносится около 60 т растворенного вещества, в том числе примерно 15 т серной кислоты [Знаменский, Никитина, 1985].

В верховьях русла ручья Кипящая Речка обнаружено большое количество крупных полуокатанных и окатанных обломков (до 10-20 см) эффузивных пород от андезибазальтового до андезидацитового состава. При раскалывании валуны и галька пород обнаруживают четко выраженное зональное строение, подчеркнутое последовательным, в виде нескольких полос, изменением цвета породы от темно-серого до белого (рис. 1а; образцы А-4, Б-8, С-2, Л-1). В некоторых образцах наблюдается зона с ярко выраженным ожелезнением, придающим породе желтую, рыжую, бурую окраску (образцы В-6, В-2). Замечено, что практически все валуны эффузивных пород, находящиеся в русле ручья, в той или иной мере подвержены процессам геохимической переработки. Встречаются как слабо переработанные, с 
едва намечающимися 1-2 зонами изменений, так и полностью измененные, белые, рыхлые, сильно пористые породы.

Для исследований были отобраны наиболее типичные образцы валунов и гальки с наибольшим количеством зон изменения. Обломки находились ниже по ручью от места разгрузки термальных источников на расстоянии 100-200 м. В каждом из образцов от центральной части к внешнему краю по цвету и текстурным особенностям выделяется от 3 до 5 зон шириной 1-3 см, разделенных четкими границами. Центральные части образцов сохраняют темный цвет, краевые зоны в различной степени осветлены. Границы зон концентрически зональные, часто причудливо изогнуты. Концентрическая зональность нарушается трещинами, по которым изменения проникают в центр образца (см. рис. 1б). Некоторые предварительные результаты были получены ранее и приведены в работе [Frolova et al., 2001].

\section{МЕТОДЫ ИССЛЕДОВАНИЯ}

Для детальных лабораторных исследований отобрано 6 образцов, представленных валунами, сложенными эффузивами андезибазальтового (В-2, А-4, С-2), андезитового (Б-8, Л-1) и андезидацитового (В-6) состава. Вещество из каждой зоны изучалось в лабораториях кафедры инженерной и экологической геологии геологического факультета МГУ им. М.В. Ломоносова с помощью поляризационного микроскопа (Olympus ВX41) в проходящем и отраженном свете, рентгено-флуоресцентного анализа (аналитик Е.Н. Самарин), рентгеновской дифрактометрии (дифрактометр ДРОН-3, аналитик В.Г. Шлыков) и микрозондового анализа (электронный микроскоп "Camscane-4DV", кафедра петрологии МГУ). На основании морфологического анализа исследовалось изменение порового пространства пород (аналитик А.А. Сасов). Для каждого образца от центра к краю производилось пошаговое измерение пористости (шаг составлял 2 мм). Для каждой зоны измерялись морфологические характеристики - относительная площадь пор, их средний размер, коэффициент формы и число пор. Коэффициент формы представляет собой отношение большой и малой осей эллипса, аппроксимирующего изображение поры:

$$
\mathrm{K} \phi=\mathrm{b} / \mathrm{a},
$$

где $\mathrm{a}, \mathrm{b}$ - большая и малая оси эллипса соответственно.

Данный коэффициент изменяется от 1 для пор изометричной формы до 0.01 в сильно вытянутых порах.

Из каждой зоны всех образцов изготовлены кубики или прямоугольные призмы (от 3 до
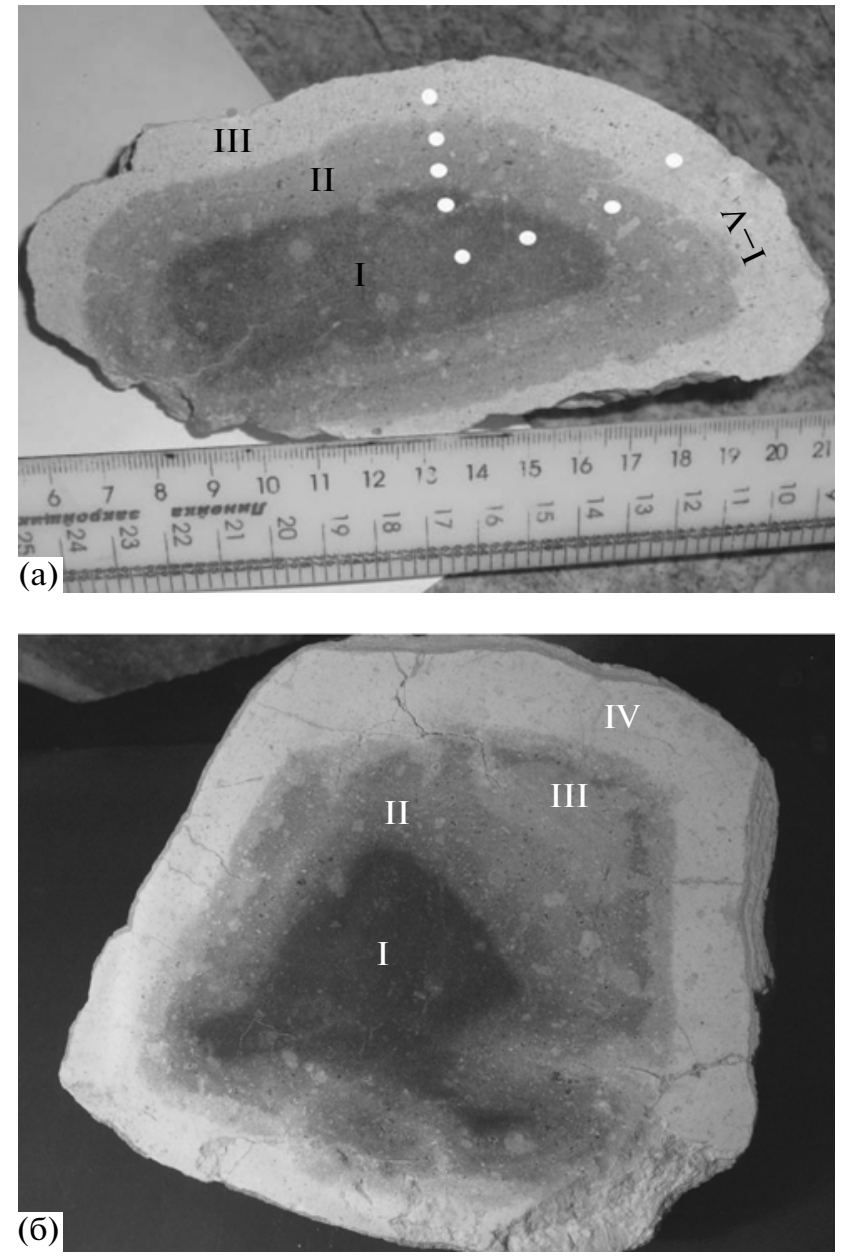

Рис. 1. Зональное строение обломков пород ручья Кипящая Речка.

а - образец Л-1, точками показаны места определения скорости продольных и поперечных волн; б - наиболее типичный образец с микротрещинами, нарушающими концентрическую зональность.

20 штук). Определялись следующие петрофизические свойства: плотность породы $(\rho)$, плотность твердой фазы (минеральная плотность) $\left(\rho_{\mathrm{s}}\right)$, пористость $(\mathrm{n})$, водопоглощение $(W)$, открытая пористость $\left(\mathrm{n}_{\mathrm{o}}\right)$, скорость распространения продольных волн $\left(V_{\mathrm{p}}\right)$, прочность на одноосное сжатие $\left(\mathrm{R}_{\mathrm{c}}\right)$, магнитная восприимчивость $(\chi)$. Для образцов Л-1 и В-2 определение скорости распространения продольных волн, помимо кубиков, проводилось на срезе образцов с помощью точечных датчиков (прибор “Ультразвук”) (см. рис. 1а). Все определения выполнены по стандартным методикам [Лабораторные работы ..., 2008].

\section{РЕЗУЛЬТАТЫ ИССЛЕДОВАНИЙ}

Образцы делятся на две группы. В образцах группы I (C-2, Б-8, Л-1, А-4) изменение цвета 

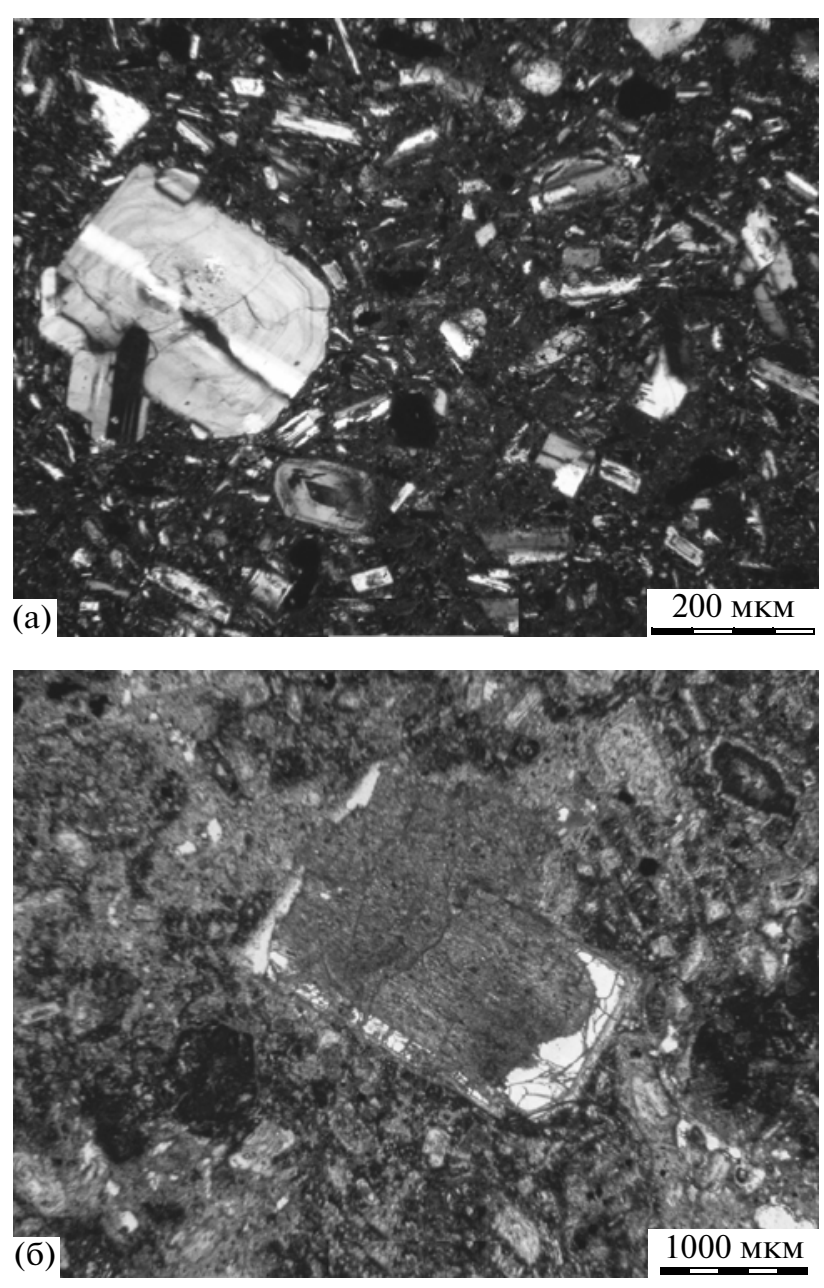

Рис. 2. Андезибазальт порфировый (обр. С-2).

а - центральная зона, видна хорошая сохранность кристаллов плагиоклаза, николи скрещены; б-внешняя зона, псевдоморфное замещение кристаллов плагиоклаза и основной массы аморфным кремнистым веществом, николи скрещены.

происходит последовательно: от темно-серых и черных тонов в центре до молочных и снежно-белых по краям (см. рис. 1). В образцах группы II (B-2, В-6) также наблюдается изменение цвета и осветление породы, но в отличие от предыдущей группы появляется слой рыжего или бурого цвета, связанный с накоплением гидрооксидов железа, за которым следует более светлый прослой. Ниже приводится детальная петрографическая и петрофизическая характеристика изученных образцов согласно разделению на эти две группы.

\section{Образиы группы I}

Андезибазальт порфировый (C-2). Порода темно-малинового цвета, порфировой структуры, массивной текстуры. На фоне афанитовой основной массы выделяются фенокристаллы плагиоклазов размером 1-2 мм, реже встречаются более крупные кристаллы - до 5-6 мм. Кристаллы пироксенов достигают 2 мм. Количество вкрапленников около 25-40\%. Основная масса гиалопилитово-интерсертальная, микролиты плагиоклазов имеют размеры до 0.1 мм.

В образце выделяются три зоны: центральная темно-малиновая (I), светло-малиновая (II) и внешняя розово-белая (III). В центральной части образца (I) по данным рентгеноструктурного анализа содержится 30-40\% плагиоклаза, представленного лабрадором, и до $30 \%$ пироксенов. Минералы, в основном, свежие (рис. 2a), но у некоторых кристаллов плагиоклазов центральные части подверглись вторичным преобразованиям. Кристаллы пироксенов с опацитовыми каемками. В клинопироксенах наблюдаются темные островки, предположительно сложенные глинистым минералом. Вполне вероятно, что это не следствие сернокислотного выщелачивания, а более ранние преобразования. Вулканическое стекло - менее стойкое к преобразованиям, по нему уже в центральной зоне образца развивается криптокристаллический кристобалит, содержание которого составляет 22\% (табл.1). В зоне II в два раза уменьшается количество плагиоклаза, происходит его замещение минералами кремнезема. Количество кристобалита возрастает до 69\%. В зоне III (внешней) порода полностью замещена минералами кремнезема (см. рис. 2б). Просматриваются отдельные реликты фенокристаллов плагиоклаза, а большая часть кристаллов псевдоморфно замещена кремнеземом. Также сохраняются отдельные зерна пироксенов, для которых характерны извилистые микротрещины, заполненные кремнеземом.

По данным микрозондового анализа от зоны I к III наблюдается изменение состава матрикса породы. Наблюдается вынос большинства петрогенных компонентов: Al от 17.6 до 4.9\%, Fe 4.1$0.6 \%, \mathrm{Mg} 2-0.2 \%$, Сa 5.8-0.6\%, Na 3.4-0.8\%, при этом существенно увеличивается количество Si от 63.5 до $84.8 \%$. Остается постоянным содержание К (1.6-2.2\%) и Ті (0.5-1\%).

По данным морфологического анализа пористость породы плавно увеличивается от центра образца (16.5\%) к краевой зоне (39\%). На границах зон наблюдается некоторое (в данном случае незначительное) уплотнение. Средний размер пор увеличивается от центра (30 мкм) к краю (45 мкм) образца, однако зона II выделяется крупными порами (54 мкм). Число пор также возрастает от центра к внешней зоне по мере выщелачивания породы, но форма пор практически не меняется (табл. 2).

Плотность породы от центра к краю ступенчато снижается: $2.54 \rightarrow 2.17 \rightarrow 1.78$ г/ $\mathrm{cm}^{3}$, пористость возрастает в 3 раза от 12 до $36 \%$ (см. табл. 2). Отме- 
Таблица 1. Минеральный состав изученных образцов по данным рентгеновской дифрактометрии (вес. \%)

\begin{tabular}{|c|c|c|c|c|c|c|c|c|}
\hline \multirow{3}{*}{ Образец } & \multirow{3}{*}{ Зона } & \multicolumn{7}{|c|}{ Минералы } \\
\hline & & \multicolumn{2}{|c|}{ первичные } & \multicolumn{5}{|c|}{ вторичные } \\
\hline & & Пл & Пр & $\mathrm{Tp}$ & Кб & $\mathrm{K}_{\mathrm{B}}$ & Алб & Ад \\
\hline \multirow[t]{3}{*}{ B-2 } & 1 & 41 & 22 & $16-18$ & 23 & & & \\
\hline & 2 & 31 & $17-18$ & $14-15$ & 35 & & & \\
\hline & 3 & 28 & $10-12$ & $15-20$ & 37 & & & \\
\hline \multirow[t]{4}{*}{ B-6 } & 1 & 20 & & & $15-17$ & $57-60$ & & \\
\hline & 2 & 51 & & & 13 & 31 & & \\
\hline & 3 & 9 & & & 18 & 71 & & \\
\hline & 4 & & & & 15 & 75 & 3 & 6 \\
\hline \multirow[t]{2}{*}{$\mathrm{C}-2$} & 1 & 40 & 32 & & 22 & & & \\
\hline & 2 & 22 & & & 69 & & & \\
\hline \multirow[t]{4}{*}{ Б-8 } & 1 & $40-42$ & $20-24$ & $12-15$ & 20 & & & \\
\hline & 2 & 20 & 40 & 20 & 23 & & & \\
\hline & 3 & 20 & 13 & 35 & 22 & & & \\
\hline & 4 & 20 & & $30-32$ & 39 & 5 & & \\
\hline \multirow[t]{3}{*}{ A-4 } & 1 & 14 & & 6 & 55 & & & \\
\hline & 2 & 21 & & & 68 & 2 & & \\
\hline & 3 & & & $7-10$ & 90 & & & \\
\hline
\end{tabular}

Примечание. Пл - плагиоклазы, Пр - пироксены, Тр - тридимит, Кб - кристобалит, Кв - кварц, Алб - альбит, Ад - адуляр. Определения выполнены на Геологическом факультете МГУ, аналитик В.Г. Шлыков. Количественный анализ проводился только по кристаллическому веществу (без учета рентгено-аморфного вещества).

тим, что величина пористости, полученная расчетным путем, совпадает с данными морфологического анализа. Скорость распространения продольных волн снижается в соответствии с уменьшением плотности и повышением пористости: $4.2 \rightarrow 2.65 \rightarrow 2.2 \mathrm{KM} / \mathrm{c}$. Прочность снижается в 5 раз - от 106 до 22 МПа. Магнитная восприимчивость характеризуется невысокими значениями в центральной части образца $\left(4.9 \times 10^{-3}\right.$ СИ) и очень низкими (до $0.7 \times 10^{-3}$ СИ) в наиболее переработанной краевой зоне.

Андезит (Б-8). Порода темно-серая, плотная, массивная. В образце выделено пять зон, цвет последовательно меняется от темно-серого в центральной части (I) до белого в внешней зоне (V). Порода обладает серийно-порфировой структурой, во вкрапленниках преобладают плагиоклазы, отмечаются моноклинные пироксены. Плагиоклаз представлен лабрадором. Размеры вкрапленников по удлинению от 0.3 до 3 мм. Отмечаются гломеропорфировые сростки. Основная масса интерсертальная, много мелких $(\leq 0.05$ мм) кристаллов плагиоклазов и пироксенов. Количество рудных минералов до 5-7\%.

В зоне I (внутренней) наблюдается частичное замещение кристаллов лабрадора минералами кремнезема. В зоне II вкрапленники в большей степени замещены адуляром и кремнеземом. Остались “островки” первичных минералов. Матрикс представлен бурой сплошной массой. В зонах III-V порода полностью изменена и сложена преимущественно минералами кремнезема кристобалитом и опалом. Отдельные участки плагиоклазов замещены аллофаном и гипсом. В зоне V сохраняются реликты кристаллов пироксенов. В проходящем свете при скрещенных николях порода представляет собой однородную темно-серую оптически изотропную массу со слабо просвечивающимися кристаллами пироксенов и плагиоклазов.

От центральной части к внешним зонам по данным рентгеновской дифрактометрии последовательно уменьшается количество первичных минералов: плагиоклаза от $40 \%$ до $10 \%$, пироксена от 20-40\% до полного исчезновения (хотя в шлифах реликты пироксенов просматриваются). Возрастает количество тридимита от 1215\% до 30-35\%, кристобалита от 20 до 39\%, появляется кварц (см. табл. 1). По данным микрозондового анализа химический состав матрикса заметно меняется от центра к краю образца. Содержание $\mathrm{Si}$ меняется в следующей последовательности: $64.3 \rightarrow 82.8 \rightarrow 89.9 \rightarrow 94.9 \rightarrow 89 \%$. 
Таблица 2. Изменение морфологических характеристик и петрофизических свойств пород согласно выделенным зонам

\begin{tabular}{|c|c|c|c|c|c|c|c|c|c|c|c|c|c|c|c|}
\hline \multirow[b]{2}{*}{$\begin{array}{l}\text { № } \\
\text { обр. }\end{array}$} & \multirow[b]{2}{*}{ Зона } & \multicolumn{4}{|c|}{$\begin{array}{c}\text { Морфологические } \\
\text { характеристики }\end{array}$} & \multicolumn{10}{|c|}{ Петрофизические свойства } \\
\hline & & 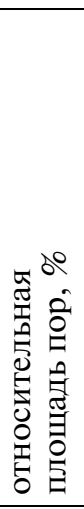 & 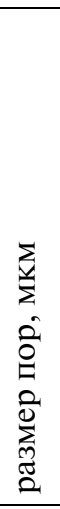 & 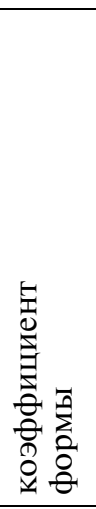 & 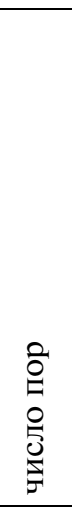 & 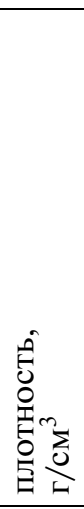 & 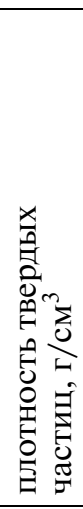 & $\begin{array}{l}\text { de } \\
\hat{0} \\
0 \\
0 \\
0 \\
0 \\
0 \\
0 \\
0\end{array}$ & 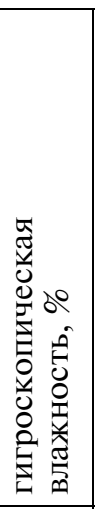 & 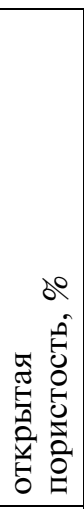 & 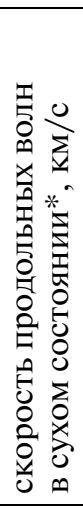 & 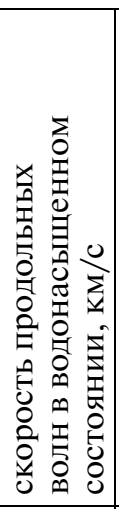 & 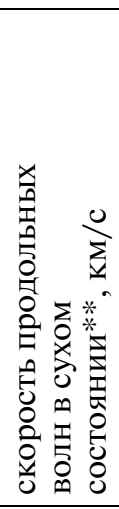 & 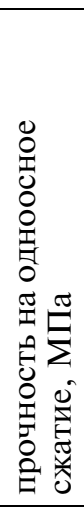 & 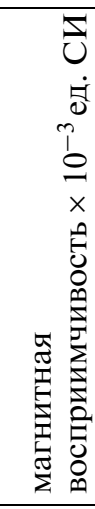 \\
\hline \multirow[t]{4}{*}{ B-2 } & 1 & 24.5 & 47 & 0.53 & 183 & 2.28 & 2.87 & 21 & 1 & 11 & 3.8 & 4.25 & - & - & 29 \\
\hline & 2 & 44.5 & 46 & 0.57 & 341 & 2.12 & 2.70 & 21 & 2.1 & 11 & 3.2 & 3.7 & 3.7 & 51 & 3.1 \\
\hline & $3 a$ & \multirow[t]{2}{*}{52} & \multirow[t]{2}{*}{50} & \multirow[t]{2}{*}{0.63} & \multirow[t]{2}{*}{336} & 1.72 & 2.61 & 34 & 3.2 & 19 & 1.95 & 2.85 & 2.4 & 22 & 0.5 \\
\hline & 36 & & & & & 1.52 & 2.51 & 39 & 3 & 31 & 1.5 & 1.9 & 1.8 & 7 & 0.3 \\
\hline \multirow[t]{5}{*}{ B-6 } & 1 & 24.4 & 37 & 0.53 & 289 & 2.40 & 2.68 & 10 & 1.1 & 9 & 3.15 & 4.1 & - & 80 & 0.6 \\
\hline & 2 & 31.1 & 39 & 0.64 & 339 & 2.23 & 2.66 & 16 & 0.9 & 10 & 2.65 & 3.45 & - & 24 & 0.5 \\
\hline & 3 & 46.4 & 51 & 0.61 & 289 & 1.96 & 2.65 & 26 & 0.9 & 20 & - & 2.3 & - & 8 & 0.4 \\
\hline & 4 & 74.3 & 75 & 0.69 & 214 & 1.65 & 2.78 & 41 & 1.1 & 27 & 2.15 & 2.3 & - & 4 & 0.4 \\
\hline & 5 & - & - & - & - & 1.42 & 2.76 & 49 & 1.1 & 37 & 1.55 & 1.8 & - & 3 & 0.35 \\
\hline \multirow[t]{3}{*}{$\mathrm{C}-2$} & 1 & 14.8 & 30 & 0.6 & 262 & 2.54 & 2.88 & 12 & 0.3 & 5 & 4.2 & 4.8 & - & 106 & 4.9 \\
\hline & 2 & 35 & 54 & 0.58 & 195 & 2.17 & 2.88 & 25 & 1.4 & 19 & 2.65 & 2.8 & - & 34 & 1.7 \\
\hline & 3 & 39 & 45 & 0.58 & 316 & 1.78 & 2.80 & 36 & 2.8 & 27 & 2.20 & 2.55 & - & 22 & 0.7 \\
\hline \multirow[t]{5}{*}{ Б- 8} & 1 & 4.1 & 22 & 0.61 & 134 & 2.78 & 2.96 & 6 & 0.9 & 1.5 & 4.0 & 4.9 & - & 181 & 30 \\
\hline & 2 & 9 & 28 & 0.55 & 188 & 2.60 & 2.73 & 5 & 1.4 & 4.8 & 2.55 & - & - & 79 & 30 \\
\hline & 3 & 6.5 & 19 & 0.66 & 284 & 2.32 & 2.55 & 9 & 2.1 & 8.2 & 2.45 & 3.65 & - & 40 & 21 \\
\hline & 4 & 20 & 27 & 0.57 & 461 & 2.12 & 2.75 & 23 & 3.2 & 12 & 1.75 & 2.75 & - & 38 & 23 \\
\hline & 5 & 78 & 53 & 0.67 & 454 & 1.83 & 2.26 & 19 & - & 18 & 2.10 & 3.1 & - & 55 & 0.4 \\
\hline \multirow[t]{3}{*}{ Л-1 } & 1 & - & - & - & - & 2.65 & 2.85 & 7 & 0.76 & - & - & - & 4.6 & - & - \\
\hline & 2 & - & - & - & - & 2.1 & 2.60 & 19 & 3.51 & - & - & - & 2.5 & - & - \\
\hline & 3 & - & - & - & - & 1.35 & 2.40 & 44 & 4.27 & - & - & - & 1.75 & - & - \\
\hline \multirow[t]{3}{*}{ A-4 } & 1 & 16.5 & 34 & 0.6 & 241 & 1.96 & 2.35 & 17 & - & 15 & 2.85 & 3.6 & - & & 19 \\
\hline & 2 & 25.9 & 38 & 0.59 & 292 & 1.64 & 2.23 & 26 & 2.8 & 23 & 2.45 & 3.2 & - & 15 & 4 \\
\hline & 3 & 64.5 & 76 & 0.58 & 184 & 1.51 & 2.15 & 30 & 3.5 & 24 & 1.80 & 2.6 & - & 13 & 0.2 \\
\hline
\end{tabular}

Примечание. Определения выполнены на геологическом факультете МГУ авторами. Метод определения $V_{\mathrm{p}}$ : * на образцах кубической формы; ** на пластинках точечными датчиками.

Количество $\mathrm{Al}$ снижается от $17.7 \%$ в центре до $1-2 \%$ в зонах III-V. Также происходит вынос $\mathrm{Fe}, \mathrm{Mg}, \mathrm{Ca}, \mathrm{Na}, \mathrm{K}$ от центра к периферии образ- ца (табл. 3). Плотность породы последовательно снижается от внутренней к внешней зоне: $2.78 \rightarrow 2.60 \rightarrow 2.32 \rightarrow 2.12 \rightarrow 1.83$ г $/ \mathrm{cm}^{3}$. Значе- 
Таблица 3. Химический состав матрикса и плагиоклазов в изученных образцах по данным микрозондового анализа (вес. \%)

\begin{tabular}{|c|c|c|c|c|c|c|c|c|c|c|}
\hline № обр. & $\begin{array}{c}\text { Исследуемый } \\
\text { участок }\end{array}$ & Зона & $\mathrm{SiO}_{2}$ & $\mathrm{TiO}_{2}$ & $\mathrm{Al}_{2} \mathrm{O}_{3}$ & $\mathrm{Fe}_{2} \mathrm{O}_{3}$ & $\mathrm{MgO}$ & $\mathrm{CaO}$ & $\mathrm{Na}_{2} \mathrm{O}_{3}$ & $\mathrm{~K}_{2} \mathrm{O}$ \\
\hline \multirow[t]{6}{*}{ B-2 } & \multirow[t]{3}{*}{$\mathrm{M}$} & 1 & 70 & 0.5 & 12.2 & 3.1 & 1.1 & 2.5 & 2.8 & 1.8 \\
\hline & & 2 & 78.1 & 0.8 & 9.3 & 2.0 & 0.1 & 0.9 & 2.6 & 2.6 \\
\hline & & 3 & 80.7 & 0.5 & 8.6 & 0.6 & 0.1 & 0.7 & 2.3 & 3.7 \\
\hline & \multirow[t]{3}{*}{ Пл } & 1 & 53.8 & 0.1 & 28.3 & 0.8 & 0.2 & 10 & 5.7 & 0.4 \\
\hline & & 2 & 64.6 & H.o. & 19.5 & 0.4 & H.o. & 1.0 & 3.9 & 0.5 \\
\hline & & 3 & 55.7 & 0.05 & 27.7 & 0.6 & 0.2 & 9.4 & 6.0 & 0.2 \\
\hline \multirow[t]{8}{*}{ Б- 8} & \multirow[t]{4}{*}{$\mathrm{M}$} & 1 & 64.3 & 0.5 & 17.7 & 3.1 & 1.6 & 6.1 & 3.7 & 1.6 \\
\hline & & 2 & 82.8 & 0.6 & 6.8 & 2.7 & 1.0 & 1.0 & 1.7 & 1.8 \\
\hline & & 3 & 89.9 & 0.7 & 2.1 & 0.5 & H.o. & 0.9 & 0.5 & 0.6 \\
\hline & & 4 & 94.9 & 0.7 & 2.4 & 0.5 & 0.2 & 0.7 & 0.8 & 0.2 \\
\hline & \multirow[t]{4}{*}{ Пл } & 1 & 51 & 0.05 & 31.5 & 0.5 & H.o. & 13 & 3.4 & 0.2 \\
\hline & & 2 & 54.3 & H.o. & 29.2 & 0.3 & 0.5 & 10.7 & 4.8 & 0.3 \\
\hline & & 3 & 62 & 0.2 & 15.7 & 0.4 & 0.1 & 1.4 & 2.3 & 0.4 \\
\hline & & 4 & 97.2 & 0.2 & 1.2 & 0.2 & H.o. & 0.2 & 0.3 & 0.2 \\
\hline \multirow[t]{7}{*}{ A-4 } & \multirow[t]{4}{*}{$\mathrm{M}$} & 1 & 84.5 & 0.5 & 3.8 & 2.0 & 0.2 & 0.4 & 0.8 & 0.3 \\
\hline & & 2 & 84 & 0.6 & 6.8 & 2.0 & 0.1 & 0.5 & 1.4 & 0.3 \\
\hline & & $3 a$ & 91.7 & 0.5 & 1.5 & 0.5 & 0.2 & 0.4 & 0.5 & 0.02 \\
\hline & & 3 & 92.5 & 0.6 & 1.7 & 0.2 & 0.2 & 0.3 & 0.5 & 0.5 \\
\hline & \multirow[t]{3}{*}{ Пл } & 1 & 54.3 & 0.1 & 28.6 & 0.7 & 0.4 & 10.2 & 5.1 & 0.2 \\
\hline & & 2 & 54.5 & 0.1 & 28.3 & 0.5 & 0.3 & 10.3 & 5.1 & 0.1 \\
\hline & & 3 & 53.2 & 0.1 & 29.7 & 0.5 & 0.2 & 11.2 & 4.7 & 0.1 \\
\hline
\end{tabular}

Примечание. М - матрикс (основная масса) породы; Пл - плагиоклаз. Состав плагиоклазов: в образце В-2 - андезин $\left(\mathrm{Ca}_{48.1} \mathrm{Na}_{49.8} \mathrm{~K}_{2.1}\right)$, в образце Б-8 - лабрадор $\left(\mathrm{Ca}_{66.9} \mathrm{Na}_{32.0} \mathrm{~K}_{1.1}\right)$, в образце $\mathrm{A}-4-$ не определен. Н.о. - не определено. Исследования выполнены на геологическом факультете МГУ авторами.

ния $V_{\mathrm{p}}$ уменьшаются от 4.0 до $1.75-2.1 \mathrm{KM} / \mathrm{c}$, но закономерная последовательность снижения скорости продольных волн от зоны к зоне несколько нарушена (см. табл. 2).

Изменение пористости в этом образце имеет свои особенности. В первых трех зонах повышение пористости незначительно: от 5 до 9\%, но в зоне IV наблюдается резкий скачок пористости до $23 \%$. Для зоны V характерны расхождения в значениях пористости, полученных двумя методами (расчетным путем и с помощью морфологического анализа): расчетная цифра равна $19 \%$, а по данным морфологического анализа - до $70 \%$ (рис. 3a, 3б). Это может быть обусловлено неравномерным распределением пор в породе, при котором морфологический анализ дает завышенный результат. Размер пор остается постоянным в зонах I-IV (19-28 мкм) и увеличивается во внешней зоне до 53 мкм. Возрастает число пор. Магнитная восприимчивость зон I и II характеризуется высокими величинами $\left(30 \times 10^{-3}\right.$ СИ), далее в зонах III и IV происходит снижение до (21-23) $\times 10^{-3}$ СИ, во внешней зоне наблюдается резкое падение ее значений до $0.4 \times 10^{-3}$ СИ.

Андезит мелкопорфировый (Л-1). Порода серая, плотная. Размер вкрапленников плагиоклазов, в среднем, 0.5 мм, отдельные кристаллы достигают 4.5 мм. Пироксены мелкие (до 0.5 мм), редкие. В образце выделяются три зоны. В центральной зоне (I) кристаллы плагиоклазов в большинстве случаев свежие, пироксены слабо изменены. Основная масса сложена вулканическим стеклом с микролитами плагиоклазов. На отдельных участках происходит замещение вулканического стекла минералами кремнезема. Визуально это проявляется в осветлении породы. Такие участки расположены хаотически, имеют округлые очертания. Эти светлые участки перемежаются с темными, где изменения не произошли.

В зонах II и III вкрапленники плагиоклазов и пироксенов полностью изменены, от них остались “силуэты”. Вулканическое стекло тоже тем- 
(a)

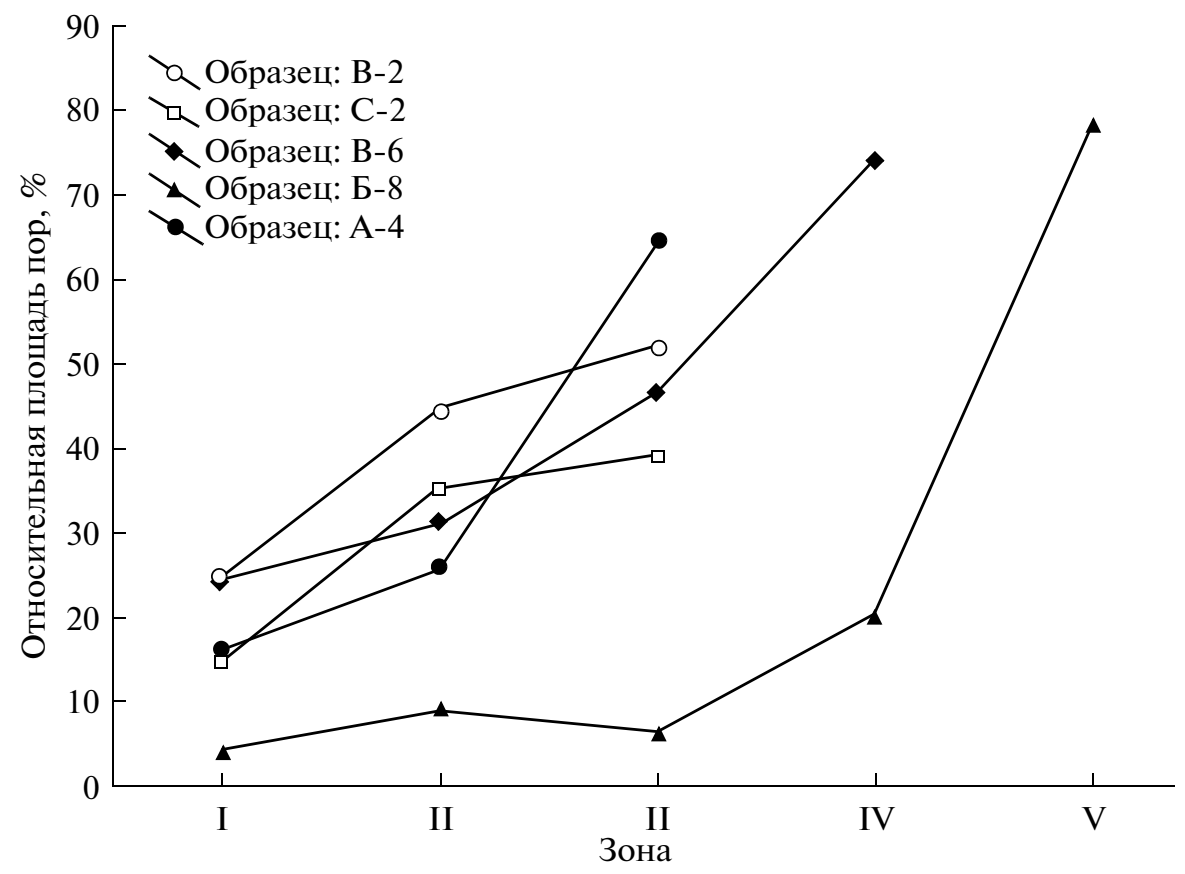

(б)
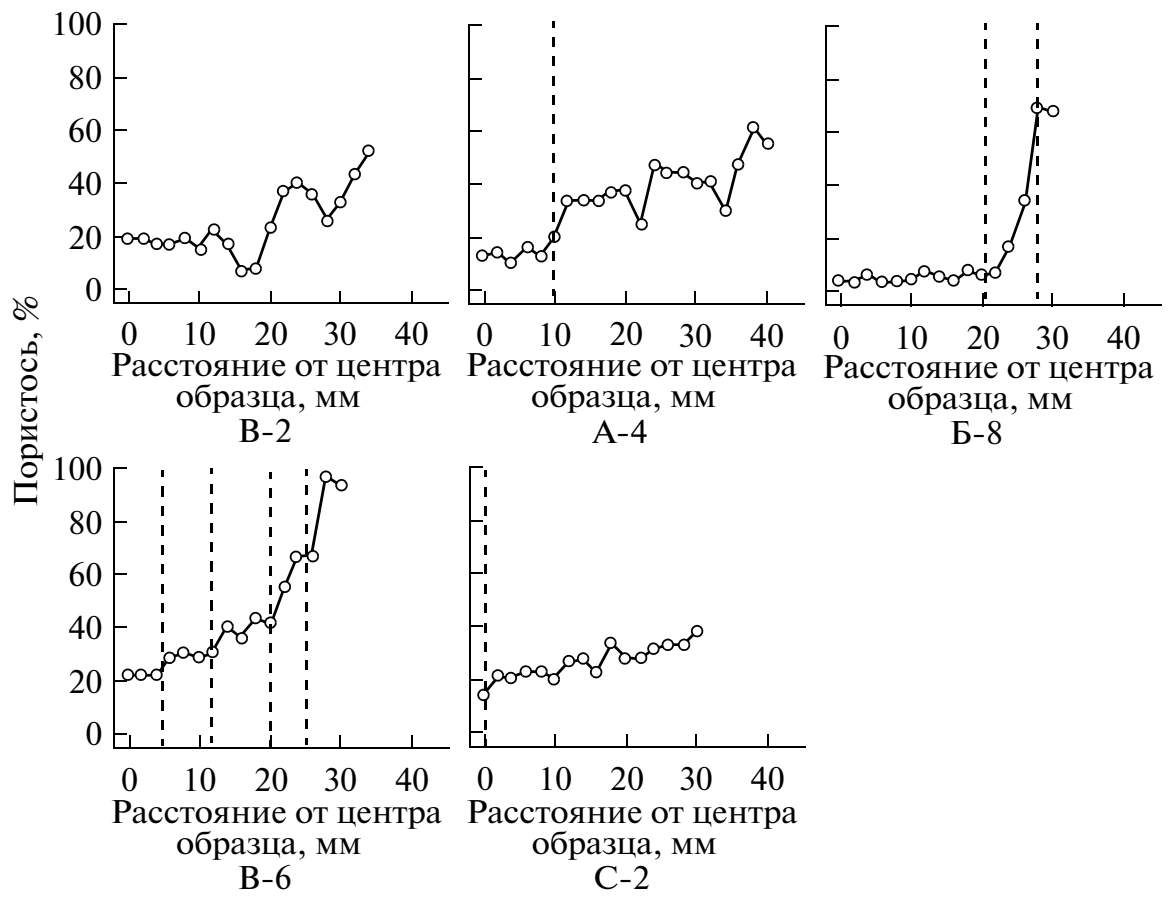
образца, мм

A-4 образца, мм Б-8

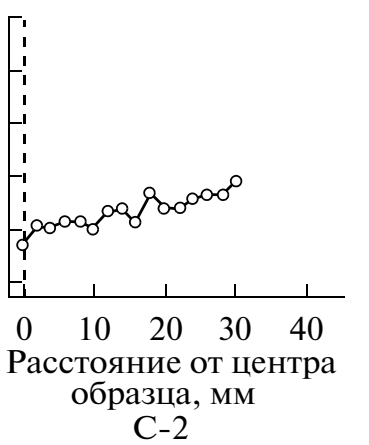

Рис. 3. Изменение пористости пород по данным морфологического анализа.

a - средняя величина пористости по зонам; б - профиль пористости от центральных частей образцов к внешним зонам.

ное оптически изотропное, но полностью переработанное, предположительно замещено опалом. В зоне III остаются “силуэты” вкрапленников плагиоклазов и фрагменты зерен пироксенов. Судя по различию в цвете, кристаллы плагиоклазов и вулканическое стекло замещено различными модификациями кремнезема.

Как и в других образцах, плотность породы уменьшается от внутренней (I) к внешней (III) зо-

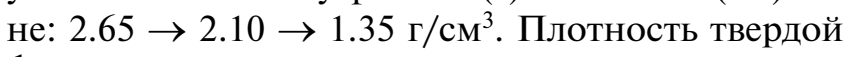
фазы снижается по мере замещения первичных 
минералов и вулканического стекла кремнеземом: $2.85 \rightarrow 2.60 \rightarrow 2.40$ г/ $\mathrm{cm}^{3}$. Пористость увеличивается в 6 раз: от 7 до 44\%. Разуплотнение и формирование вторичной пористости вызывает снижение величины скорости продольных волн от 4.6 до 1.75 км/с (см. табл. 2).

Андезибазальт порфировый (А-4). Порода имеет порфировую структуру, мелкопористую текстуру. Вкрапленники представлены плагиоклазом и пироксенами размером от 0.1 до 1-2 мм. Количество вкрапленников до 30-40\% объема породы. В образце выделяются три зоны. В первой (внутренней) зоне многие вкрапленники выщелочены и о принадлежности их к конкретному породообразующему минералу можно судить только по реликтовым формам. Замещение вкрапленников, как и в других образцах, происходит избирательно. Основная масса интерсертально-гиалопилитовая, тонко раскристаллизована. Вулканическое стекло девитрифицировано, замещено кремнеземом и представляет собой бурое оптически изотропное вещество. Данные микрозондового анализа подтверждают значительное изменение основной массы, которая состоит на $84.5 \%$ из $\mathrm{SiO}_{2}$. Содержание остальных основных элементов не велико: Al 3.8\%, Fe 2\%, $\mathrm{Mg} 0.2 \%, \mathrm{Ca} 0.4 \%, \mathrm{Na} 0.8 \%, \mathrm{~K} 0.3 \%$ (см. табл. 3).

Как и в других образцах, от зоны I к III переработка вещества увеличивается. Внешняя зона светло-бежевого цвета, порфировая структура породы сохраняется; текстура мелкопористая, пористость увеличивается. Содержание $\mathrm{SiO}_{2}$ в матриксе повышается до 92.5\%. По данным рентгенофазового анализа внешняя зона сложена минералами кремнезема - тридимитом (7-10\%) и кристобалитом (90\%) (см. табл. 1). Во всех зонах сохраняются реликты пироксенов, хотя основной объем их кристаллов обычно замещен кремнеземом.

По данным морфологического анализа пористость от внутренней зоны к внешней повышается в четыре раза - от 16 до 65\%. На границах зон отмечаются участки уплотнения, образование которых, по-видимому, связано с осаждением в порах плотного аморфного кремнезема. Размер пор увеличивается от 34 до 75 мкм, коэффициент формы не меняется (см. табл. 2). По сравнению с другими образцами для центральной части харак-

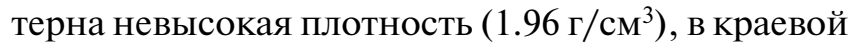
зоне она снижается до $1.51 \mathrm{\Gamma} / \mathrm{cm}^{3}$. Значения $V_{\mathrm{p}}$ уменьшаются от 2.85 км/с до 1.8 км/с. Изменение этих свойств обусловлено замещением основной массы породы, наиболее интенсивно - в краевой зоне. Выщелачивание железа и разложение рудных минералов приводит к снижению магнитной восприимчивости от $19 \times 10^{-3}$ СИ до $0.2 \times 10^{-3}$ СИ (см. табл. 2).

\section{Образцы группы II}

Андезибазальт порфировый (В-2). Порода темно-серого цвета с порфировой структурой, массивной текстурой, без видимых открытых пор. По изменению цвета в образце выделяются три зоны: центральная часть темно-серая (I), рыжая полоса шириной до 1.5 см (II) и внешняя зона светло-серой и бежевой окраски (III). Цвет зоны зависит, главным образом, от изменения основной массы. Порфировые вкрапленники представлены плагиоклазом (1-3 мм, до 5 мм по удлинению), в меньшей степени - пироксеном (до 1 мм). Порфировая структура породы сохраняется и во внешней зоне, однако там вкрапленники псевдоморфно замещены вторичными минералами и выделяются в виде силуэтов на фоне осветленной основной массы породы.

Исследования шлифов и анализ химического и минерального составов показали, что интенсивность преобразований нарастает от внутренней к внешней зонам. По данным рентгеновской дифрактометрии (см. табл. 1) от центра к краю образца уменьшается количество первичных минералов: плагиоклаза от 41 до $28 \%$, пироксена - от 22 до 10\%. Это связано с их замещением вторичными минералами, в первую очередь, низкотемпературными полиморфными модификациями $\mathrm{SiO}_{2}$ - кристобалитом, тридимитом, опалом. Следует отметить, что высокое содержание минералов кремнезема (около 40\%), замещающих преимущественно матрикс породы (вулканическое стекло), наблюдается уже в центральной части образца (см. табл.1). Это свидетельствует о том, что либо порода ранее подвергалась гидротермальной переработке, либо изменения достигли центральной части валуна. В любом случае эта порода уже не является свежим андезибазальтом. Во внешней зоне образца содержание минералов кремнезема повышается до 52-57\%, это происходит за счет образования кристобалита, тогда как количество тридимита остается прежним.

Под воздействием термальных вод происходит вынос из породы большинства петрогенных компонентов $-\mathrm{Al}_{2} \mathrm{O}_{3}$ от 22.9 до $7.8 \%, \mathrm{FeO}$ от 8.1 до $2.6 \%, \mathrm{MgO}$ от 1.9 до $0.7 \%, \mathrm{CaO}$ от 5.9 до $1.4 \%$. Coдержание $\mathrm{SiO}_{2}$, напротив, увеличивается от 54\% во внутренней зоне, до $66 \%$ во внешней зоне (табл. 4).

Замечено, что характер изменений различен для матрикса породы, плагиоклазов и пироксенов. В шлифах видно, что значительные изменения претерпевают фенокристаллы плагиоклазов. В центральной зоне плагиоклазы изменены в наименьшей степени. Но наблюдается выборочное преобразование: одни кристаллы изменены значительно, в других изменения происходят вдоль микротрещин. Это может быть связано как с различным составом плагиоклазов, так и с изби- 
Таблица 4. Химический состав изученных зональных образцов по данным рентгено-флуоресцентного анализа (об. \%)

\begin{tabular}{|c|c|c|c|c|c|c|c|c|c|}
\hline № обр. & № зоны & $\mathrm{SiO}_{2}$ & $\mathrm{TiO}_{2}$ & $\mathrm{Al}_{2} \mathrm{O}_{3}$ & $\mathrm{FeO}$ & $\mathrm{CaO}$ & $\mathrm{MgO}$ & $\mathrm{K}_{2} \mathrm{O}$ & \\
\hline \multirow[t]{4}{*}{ B-2 } & 1 & 54.13 & 0.68 & 22.88 & 8.1 & 5.87 & 1.89 & 0.96 & \\
\hline & 2 & 56.38 & 0.75 & 11.96 & 4.99 & 3.56 & 1.38 & 1.5 & \\
\hline & 3 & 58.42 & 1 & 11.51 & 6.61 & 1.43 & 1.14 & 1.46 & \\
\hline & 4 & 65.9 & 0.94 & 7.82 & 2.62 & 1.39 & 0.67 & 1.39 & $\stackrel{\widetilde{g}}{\exists}$ \\
\hline \multirow[t]{5}{*}{ B-6 } & 1 & 62.37 & 0.54 & 11.05 & 3.22 & 1.9 & 0.89 & 1.64 & ล \\
\hline & 2 & 65.16 & 0.54 & 10.37 & 2.85 & 1.2 & 0.7 & 1.53 & $\Xi$ \\
\hline & 3 & 68.66 & 0.64 & 10.35 & 3.32 & 0.81 & 0.62 & 1.58 & \\
\hline & 4 & 70.09 & 0.67 & 11.61 & 3.52 & 0.42 & 0.54 & 1.65 & \\
\hline & 5 & 64.83 & 0.81 & 12.77 & 4.55 & 0.14 & 0.59 & 1.56 & \\
\hline \multirow[t]{3}{*}{$\mathrm{C}-2$} & 1 & 57.12 & 0.7 & 24.92 & 7.74 & 6.4 & 2.04 & 0.67 & \\
\hline & 2 & 69.95 & 0.95 & 16.03 & 7.34 & 3.83 & 1.95 & 0.74 & \\
\hline & 3 & 71.06 & 1.34 & 7.1 & 2.94 & 1.17 & 0.65 & 0.9 & \\
\hline \multirow[t]{5}{*}{ Б-8 } & 1 & 59.02 & 0.85 & 18.3 & 8.78 & 5.95 & 2.18 & 0.97 & \\
\hline & 2 & 74.11 & 0.98 & 13.73 & 8.65 & 4.08 & 2.05 & 0.64 & \\
\hline & 3 & 85.37 & 0.96 & 7.19 & 6.85 & 2.22 & 1.59 & 0.65 & \\
\hline & 4 & 87.74 & 1.1 & 3.24 & 5.63 & 1.22 & 1.1 & 0.45 & $\widetilde{\Xi}$ \\
\hline & 5 & 83.98 & 1.24 & 1.15 & 3.97 & 0.81 & 0.87 & 0.21 & 光 \\
\hline \multirow[t]{3}{*}{ Л-1 } & 1 & 60.19 & 0.69 & 23.94 & 8 & 5.73 & 2.39 & 1 & $\Xi$ \\
\hline & 2 & 77.51 & 1.05 & 3.89 & 7.16 & 1.67 & 1.52 & 0.67 & \\
\hline & 3 & 85.24 & 1.4 & H.o. & 1.27 & 0.45 & 0.27 & H.o. & \\
\hline \multirow[t]{4}{*}{ A-4 } & 1 & 54.17 & 0.7 & 21.82 & 7.62 & 1.65 & 1.69 & 1.02 & \\
\hline & 2 & 58.85 & 1.04 & 11.4 & 3.95 & 0.25 & 0.45 & 0.62 & \\
\hline & $3 a$ & 80.47 & 1.17 & 587 & 0.25 & 0.45 & H.o. & 0.19 & \\
\hline & 3 & 89.4 & 1.35 & 0.25 & H.o. & H.o. & H.o. & H.o. & \\
\hline
\end{tabular}

Примечание. Приведены наиболее значимые и изменяющиеся компоненты. Н.о. - ниже предела обнаружения. Определения выполнены на Геологическом факультете МГУ, аналитик Е.Н. Самарин.

рательностью гидротермального процесса: во второй и третьей зонах остаются реликты андезина - он замещается кристобалитом, опалом и тридимитом, и в меньшей степени адуляром. Состав пироксенов от центральной к внешней зоне меняется мало: происходит частичное растворение на ослабленных участках, соответствующих дефектам в кристаллах, и замещение кремнеземом. Фронт замещения (от первичного минерала до вторичного) имеет резкий характер, его ширина составляет доли микрона. Заметное количество пироксенов сохраняется во всех зонах, в т.ч. внешней.

Для матрикса породы наблюдается увеличение содержания $\mathrm{SiO}_{2}$ от $70 \%$ в центральной части до $80 \%$ во внешней зоне (см. табл. 3). Высокое содержание кремнезема в центральной части образца подтверждает значительное гидротермальнометасоматическое преобразование породы. От центра (зона I) к краю (зона III) происходит вынос большинства компонентов $-\mathrm{Al}_{2} \mathrm{O}_{3}$ (от 12.2 до
$8.6 \%$ ), $\mathrm{FeO}$ (от 3.1 до $0.6 \%$ ), $\mathrm{MgO}$ (от 1.1 до $0.1 \%$ ), $\mathrm{CaO}$ (от 2.5 до $0.7 \%$ ), $\mathrm{Na}_{2} \mathrm{O}$ (от 2.8 до $2.3 \%$ ). Противоположную тенденцию обнаруживает $\mathrm{K}_{2} \mathrm{O}$, содержание этого компонента повышается от 1.8 до $3.7 \%$. По-видимому, это связано с частичным замещением микролитов основной массы адуляром. Содержание титана остается постоянным. Вулканическое стекло частично изменено в центральной зоне, а во всех остальных зонах полностью преобразовано и замещено агрегатом кристобалита. В целом, динамика изменения химического состава породы и ее матрикса сходна, хотя количественные показатели несколько различаются (см. табл. 3 и 4).

Морфологический анализ показал, что в процессе сернокислотного выщелачивания формируется вторичная пористость - ее значения увеличиваются от $24 \%$ в центральной части образца до $52 \%$ во внешней зоне (см. табл. 2 и рис. 3а). Размер пор меняется незначительно, но суще- 
ственно увеличивается их число. Поры становятся более изометричными, на что указывает изменение коэффициента формы от 0.53 до 0.63. Происходит последовательное изменение пористости по профилю от центральной части образца к краевой зоне (см. рис. 3б). На фоне общей тенденции ступенчатого увеличения пористости на границах зон наблюдаются локальные участки уплотнения (как и в образце С-2). Вероятно, их формирование обусловлено осаждением и концентрацией кремнистого вещества на этих участках.

В соответствии с минеральными преобразованиями изменяются свойства пород (см. табл. 2). Плотность породы закономерно уменьшается от $2.28 \Gamma / \mathrm{cm}^{3}$ в центральной части образца до

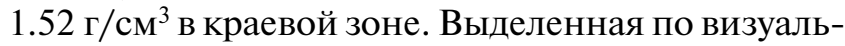
ным признакам третья зона по плотности четко

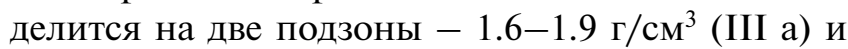

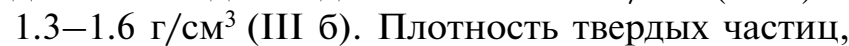
отражающая химический состав породы, закономерно уменьшается согласно выделенным зонам:

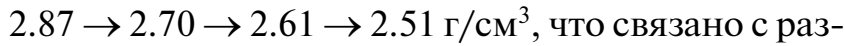
рушением более плотных первичных минералов и вулканического стекла и образованием легких минералов кремнезема. Выщелачивание породы вызывает повышение пористости в два раза - от 21 до 39\%. В соответствии с изменениями плотности и пористости уменьшаются значения скорости распространения продольных волн $V_{\mathrm{p}}$ : $3.85 \rightarrow 3.2 \rightarrow 1.95 \rightarrow 1.5 \mathrm{KM} / \mathrm{c}$. Под действием сернокислотного выщелачивания порода утрачивает магнитные свойства, что обусловлено выносом железа и разложением темноцветных и рудных минералов (магнетита, титаномагнетита и ильменита). В данном образце магнитная восприимчивость снижается на два порядка от внутренней к внешней зонам $\left(29 \times 10^{-3}\right.$ СИ-0.3 × $10^{-3}$ СИ).

Андезидацит порфировый (В-6). Порода темно-серая с порфировой структурой, массивной текстурой. На фоне основной массы выделяются светлые вкрапленники плагиоклазов размером по удлинению в среднем 4-6 мм. Основная масса гиалопилитовая. В образце выделяется пять зон. От центральной части (I) к краевой зоне (V) происходит осветление породы. В последней зоне наблюдается чередование белого, бежевого и желтого цветов, меняется текстура породы - появляются крупные поры, образованные за счет выщелачивания фенокристаллов плагиоклазов. Порода становится непрочной.

Это единственный образец, в котором изменения валового химического состава не существенны и матрикс не испытывает заметных колебаний химического состава. В частности, матрикс породы на 72-75\% состоит из $\mathrm{SiO}_{2}$ и его содержание практически не меняется от внутренней части к внешней зоне. Возможно порода была изменена ранее, до попадания в ручей, или находилась в кислой проточной среде длительное время, в течении которого все изменения сгладились. В шлифах отмечается замещение основной массы криптокристаллическим кремнистым агрегатом.

По данным рентгенофазового анализа в центральной части образца содержится $50 \%$ плагиоклаза, представленного андезином. В кристаллах андезина наблюдаются небольшие выщелоченные участки, выполненные глинистым минералом (предположительно, диккитом). Отдельные участки кристаллов замещены кремнеземом. От центра к краю образца количество плагиоклаза постепенно уменьшается до полного исчезновения во внешней зоне. До зоны III (включительно) сохраняются остатки плагиоклазов, в IV и V они полностью замещены - остаются лишь контуры (тени) первичных кристаллов, псевдоморфно замещенных минералами кремнезема. Внешняя зона (V) на $90 \%$ состоит из минералов кремнезема (кристобалит, кварц), в небольшом количестве присутствует адуляр, замещающий андезин. Во внешней зоне наблюдается увеличение количества $\mathrm{Fe}$ (от $1.1 \%$ в центре образца до $6.3 \%$ во внешней зоне) и уменьшение Са (от 1.2 до $0.4 \%$ ) и $\mathrm{Al}$ (от 14.1 до $10.7 \%$ ). За счет интенсивного ожелезнения внешняя зона приобретает бурый и желтый цвета.

Пироксены присутствуют во всех зонах. В зонах I и II в кристаллах пироксенов наблюдаются участки, выполненные минералами кремнезема, а по трещинам развиваются глинистые минералы. Отдельные реликты пироксенов сохраняются и во внешней зоне (V).

B результате выщелачивания формируется вторичная пористость, значения которой повышаются от $24 \%$ в центральной части образца до $74 \%$ в краевой (по данным морфологического анализа) (см. рис. За). Возрастание пористости носит ступенчатый характер, соответствующий выделенным зонам (см. рис. 3б). От зоны к зоне наблюдается увеличение размера пор от 37 до 75 мкм. Увеличивается коэффициент формы от 0.53 до 0.69 (см. табл. 2), что свидетельствует в пользу формирования более изометричных пор в зонах с максимальной интенсивностью выщелачивания пород. Плотность вещества последовательно снижается в соответствии с выделенными зонами: $2.40 \rightarrow 2.23 \rightarrow 1.96 \rightarrow 1.65 \rightarrow 1.42$ г/ $/ \mathrm{cm}^{3}$. Пористость возрастает в 5 раз - от 10 до 49\%. Открытая пористость ниже по сравнению с общей пористостью, ее величина увеличивается от 6 до $39 \%$ (см. табл. 2). Не наблюдается последовательного изменения плотности твердых частиц, что закономерно и находится в соответствии с химическим составом породы. В зонах I-III $\rho_{s}$ состав-

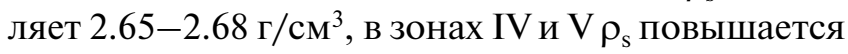

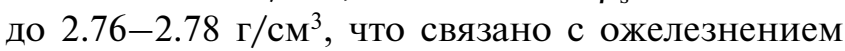
породы. Значения $V_{\mathrm{p}}$ уменьшаются от 3.15 до $1.55 \mathrm{kM} / \mathrm{c}$ в соответствии с уменьшением плотно- 
сти и повышением пористости. Минеральные и структурные преобразования породы приводят к ее существенному разупрочнению: прочность снижается от 80 до 3-4 МПа. Магнитная восприимчивость характеризуется низкими значениями. Даже в центральной части образца, на наименее измененных участках, она не превышает $4 \times 10^{-3}$ СИ.

\section{ОБСУЖДЕНИЕ РЕЗУЛЬТАТОВ}

Под воздействием термальных вод кислого, до ультракислого состава валуны и галька аллювия ручья Кипящая Речка приобретают зональное строение (независимо от первичного состава пород). Макроскопически зоны выделяются по изменению цвета - от темных тонов (черно-серых, красно-коричневых) в центральных частях образцов до светлых (бежевых, серых, розовых, белых) в краевых участках, а также на основании текстурных особенностей. В каждом изученном образце выделяется от 3 до 5 зон. Границы между зонами четкие. Зональная картина несколько нарушается в присутствии микротрещин, вдоль которых происходит более интенсивная переработка и осветление вещества, так как они являются путями для фильтрующихся термальных вод. От центральных частей образцов к внешним зонам нарастает степень гидротермальной переработки вещества, что сопровождается существенным изменением химического и минерального составов, пористости, плотности и других петрофизических характеристик породы.

Кремнезем, освобождающийся при растворении силикатов, отлагается метасоматическим путем на месте первичных минералов (иногда совместно с гидрооксидами $\mathrm{Fe}$ и $\mathrm{Al}$ ). Первичные компоненты породы - вулканическое стекло, плагиоклазы, пироксены выщелачиваются и замещаются различными низкотемпературными полиморфными модификациями кремнезема, среди которых преобладает кристобалит, а также присутствуют низкотемпературный кварц, тридимит и опал. Процесс растворения обычно преобладает над процессом осаждения вещества, в результате чего остаются пустоты выщелачивания. Преобразования начинаются с вулканического стекла, которое превращается в агрегат опала и криптокристаллического кристобалита. Вулканическое стекло в значительной степени изменено даже во внутренних частях образцов.

Преобразования фенокристаллов плагиоклазов и пироксенов начинаются по трещинам и дефектам в кристаллах. Фронт замещения, как правило, резкий. В краевых зонах образцов первичные минералы и вулканическое стекло полностью замещены минералами кремнезема, однако при этом сохраняется первичная структура породы - замещение носит псевдоморфный характер. Других вторичных минералов в значимых количествах не обнаружено. Возможно, что наблюдаемый в редких случаях глинистый материал механически вымывается проточным кислым раствором.

Валовый химический состав образцов, как правило, меняется последовательно от центра к периферии (см. табл. 4, рис. 4). От центральных зон к внешним частям отмечается увеличение количества $\mathrm{SiO}_{2}$ и уменьшение содержания $\mathrm{CaO}$ и $\mathrm{MgO}$. Содержание $\mathrm{Al}_{2} \mathrm{O}_{3}$ уменьшается у всех образцов, кроме В-6. Однако выделенные выше группы образцов характеризуются различными особенностями в изменении химического состава породы (от центральных частей к внешним).

Групnа I (С-2, Б-8, Л-1, А-4). (1) Существенное увеличение содержания $\mathrm{SiO}_{2}$ - от 54-60\% до 71$89 \%$; (2) Уменьшение содержания $\mathrm{Al}_{2} \mathrm{O}_{3}, \mathrm{FeO}, \mathrm{CaO}$, $\mathrm{MgO}, \mathrm{K}_{2} \mathrm{O}$.

Группа II (В-2, В-6). (1) Незначительное увеличение содержания $\mathrm{SiO}_{2}$; (2) Уменьшение содержания $\mathrm{CaO}$ и $\mathrm{MgO}$; (3) Содержание $\mathrm{FeO}$ и $\mathrm{K}_{2} \mathrm{O}$ варьирует.

Для всех образцов отмечается увеличение содержания $\mathrm{TiO}_{2}$. Изменение количества других компонентов - $\mathrm{MnO}, \mathrm{P}_{2} \mathrm{O}_{5}, \mathrm{~S}$ также происходит, но не настолько заметно. Вероятно, факт увеличения содержания $\mathrm{TiO}_{2}$ может представлять большой интерес в связи с отмеченной ранее высокой активностью титана в гидротермально-метасоматических процессах, характеризующихся близкими Р-Т и физико-химическими условиями (атмосферным давлением, температурой до 100$105^{\circ} \mathrm{C}$, низкими $\left.\mathrm{pH}\right)$ к рассмотренными нами. Так, Ті в количестве от 2 до 6\% входит в микроструктуры гидротермальных глин, особенно при переходе от аморфных к кристаллическим минеральным фазам [Рычагов и др., 2010]. Установлено формирование титансодержащих оксидно-силикатных минеральных пленок на поверхности кристаллов пирита, образующегося в гидротермальных глинах на термальных полях Южной Камчатки [Рычагов, Щегольков, 2011].

Выявлена последовательность минеральных преобразований на основании микроскопических исследований. В первую очередь происходит разложение стекловатого базиса эффузивной породы и замещение минералами кремнезема. В центральных частях образцов матрикс содержит 63-84\% $\mathrm{SiO}_{2}$, во внешней зоне его количество увеличивается до 85-98\%. Содержание $\mathrm{SiO}_{2}$ в матриксе всегда выше, чем общее количество $\mathrm{SiO}_{2}$ в породе, что свидетельствует о первоочередном замещении кремнеземом основной массы. Высокое содержание $\mathrm{SiO}_{2}(84 \%)$, обнаруженное в центральной части образца А-4, свидетельствует о том, что этот андезибазальт еще до попадания в ручей подвергся переработке, либо находился в ручье продолжительное время. 


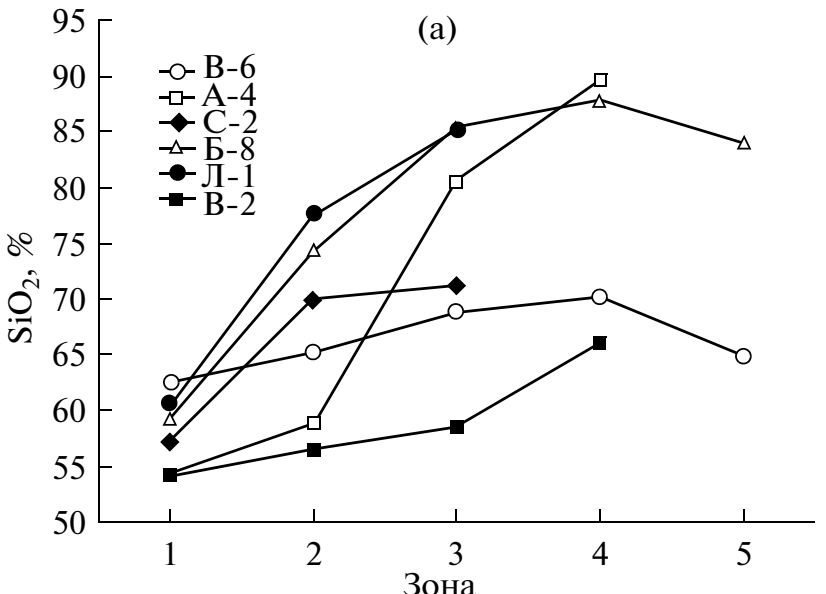

(в)

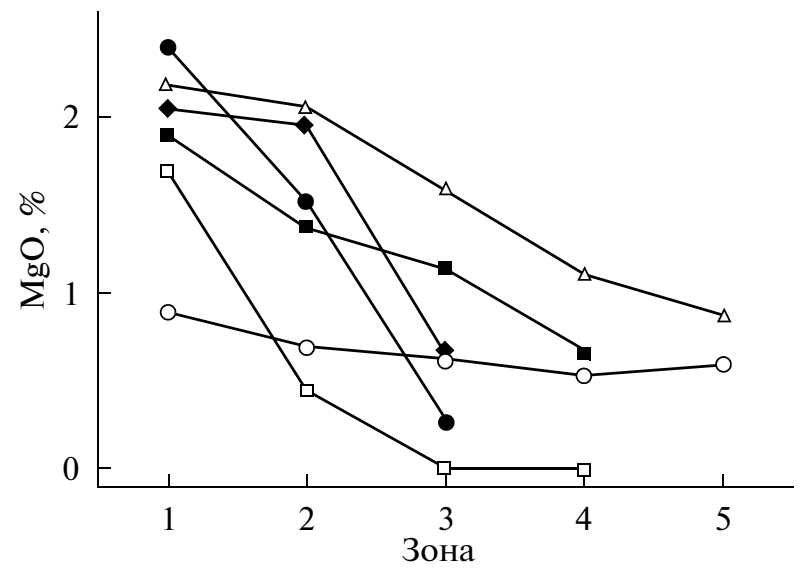

(д)

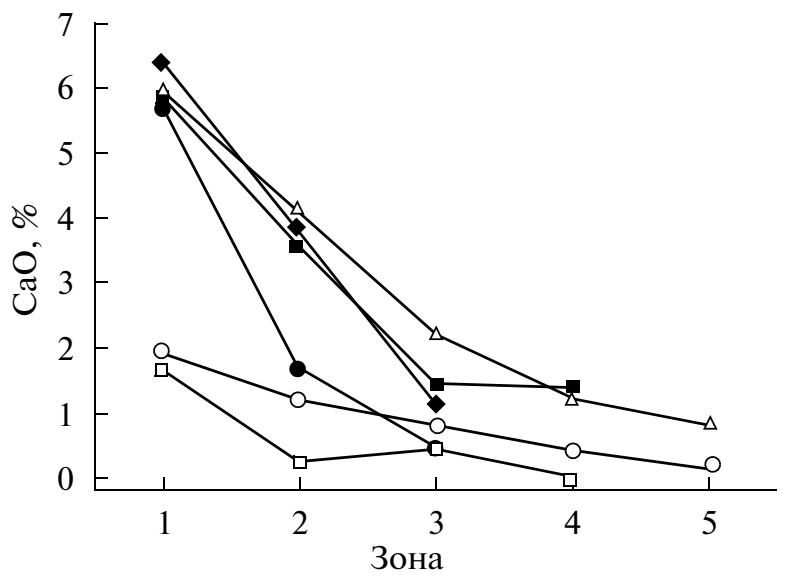

(б)

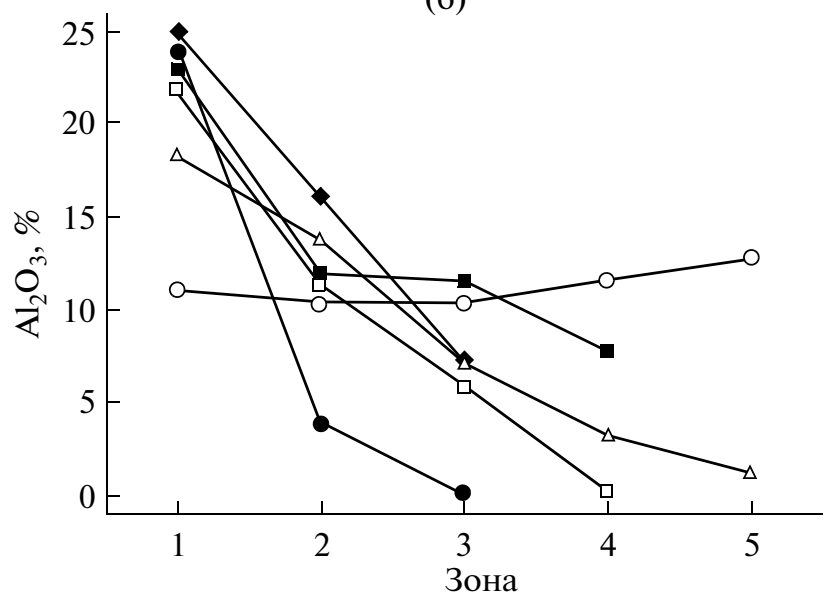

(г)

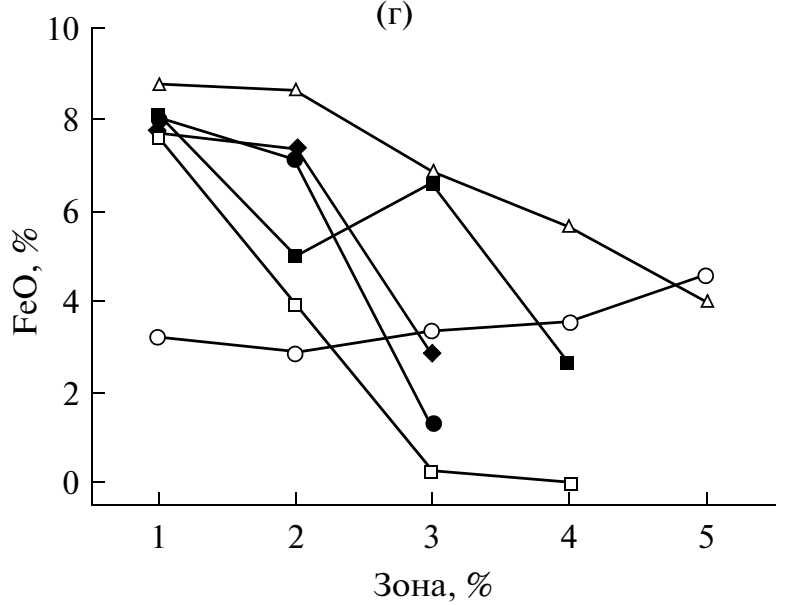

(e)

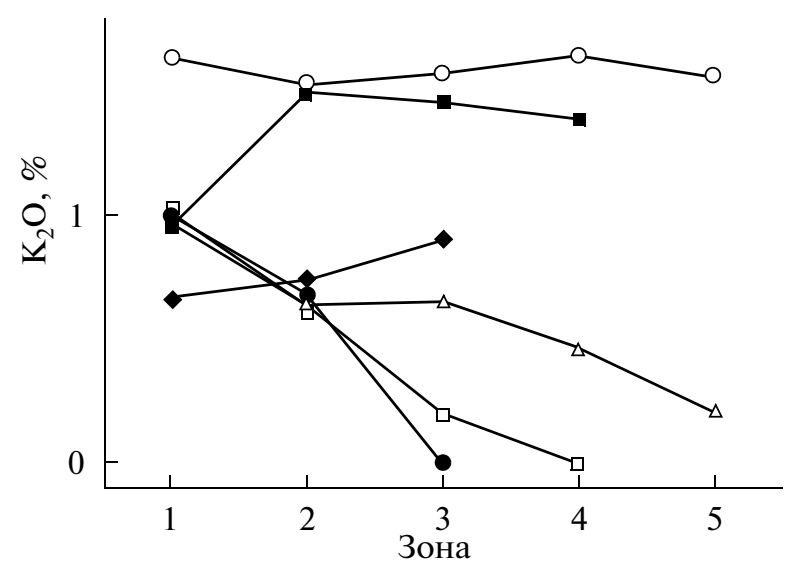

Рис. 4. Изменение содержания основных компонентов пород по данным валового химического анализа: $\mathrm{a}-\mathrm{SiO}_{2}, \sigma-\mathrm{Al}_{2} \mathrm{O}_{3}$, в $-\mathrm{MgO}$, г $-\mathrm{FeO}$, д $-\mathrm{CaO}$, e $-\mathrm{K}_{2} \mathrm{O}$.

Изменениям подвергаются как матрикс породы, так и вкрапленники плагиоклазов и пироксенов. Содержание химических компонентов в матриксе и во вкрапленниках при образовании вторичных минералов значительно различается (см. табл. 3). Плагиоклазы являются более устой- чивыми к изменениям, чем стекло. Во внутренних зонах образцов фенокристаллы плагиоклаза (лабрадор, андезин) не изменены или незначительно замещены кремнеземом по трещинам. В третьей зоне происходит активное выщелачивание и замещение центральных частей кристаллов. 
Во внешней зоне кристаллы плагиоклаза практически нацело выщелочены и псевдоморфно замещены минералами кремнезема. Пироксены наиболее устойчивы к кислым термальным водам. Наибольшее изменение наблюдается в последних зонах, где происходит резкое увеличение количества $\mathrm{SiO}_{2}$ и уменьшение содержания окислов $\mathrm{Al}$, $\mathrm{Fe}, \mathrm{Mg}$, хотя некоторое количество свежих кристаллов авгита обнаружено даже во внешней, наиболее переработанной зоне. Отмечается резкий характер границы между первичными силикатными минералами и развивающимися по ним агрегатами кремнезема. Ширина фронта замещения составляет доли микрона. Возможно количественная характеристика преобразования пироксенов в сравнении с таковыми плагиоклазов и матрикса может служить критерием оценки динамики и времени воздействия проточных кислых (ультракислых) растворов на горные породы.

Степень изменения изученных образцов различна, однако последовательность преобразований примерно одинакова для всех образцов. Преобразование химического и минерального состава вызывает изменение физического состояния пород. В результате сернокислотного выщелачивания пород формируется вторичная пористость, т.е. процесс растворения доминирует над осаждением. Конечным результатом выщелачивания является “ажурный” пористый каркас, образованный кремнистым веществом. Характерно ступенчатое увеличение пористости от внутренней $\mathrm{K}$ внешней зонам. В ряде случаев на границах зон наблюдается локальное уплотнение за счет осаждения кремнистого вещества в межкристаллическом пространстве и микропорах породы. Вследствие сернокислотного выщелачивания пород средний размер пор увеличивается от 2030 мкм до 75-80 мкм, наибольшее увеличение размера пор происходит во внешней зоне. В некоторых образцах в этой зоне образуются макропоры размером до нескольких миллиметров.

Одним из основных физических параметров горных пород является их плотность, которая определяет многие другие свойства, в частности, прочностные и деформационные. На графике (рис. 5) показано изменение плотности по мере изменения породы. Для всех образцов наблюдается четкое, закономерное снижение плотности от центральных частей к внешним. Уменьшение плотности происходит постепенно внутри зон, но носит ступенчатый характер (ступени-барьеры характеризуют границы зон), снижаясь на 0.20.3 г/ $\mathrm{cm}^{3}$ (на 6-13\%) от зоны к зоне. В целом плотность породы снижается на 30-40\% (от 2.5-2.8 до 1.35-1.5 г/ $\left.\mathrm{cm}^{3}\right)$. Разуплотнение вызвано двумя причинами: 1) снижением плотности твердых частиц (минеральной плотности), отражающей химический и минеральный состав породы; 2) выще- лачиванием и формированием вторичной пористости. Плотность твердых частиц снижается у

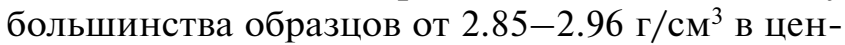

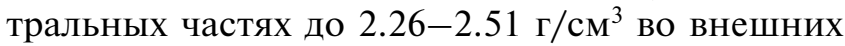
зонах. Это обусловлено разрушением плотных первичных минералов и вулканического стекла и образованием легких кремнистых минералов с низкой плотностью 2.2-2.3 г/ $\mathrm{cm}^{3}$. Исключение составляет образец В-6, плотность твердых частиц которого повышается от 2.66-2.68 до 2.76-

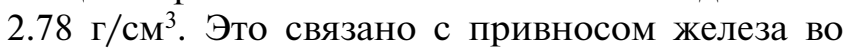
внешние зоны.

Во всех образцах (кроме В-6) с увеличением степени переработки повышается гигроскопическая влажность - от 0.3-1\% в центральной части до $2.8-4.3 \%$ в краевой зоне. Вероятно, это обусловлено образованием опала, который содержит в своей структуре большое количество молекул воды.

В соответствии с уменышением плотности меняются другие физические и механические характеристики пород (см. рис. 5 и табл. 2). Во всех образцах в результате выщелачивания растет пористость, в среднем в 2-5 раз. Снижение плотности и формирование вторичной пористости вызывает разупрочнение породы. Прочность снижается в несколько раз: в одних случаях от 200 до 4060 МПа, в других - от 100 МПа до первых единиц МПа. Скорость распространения продольных волн уменьшается от 3-4 кM/с до 1.5-2.5 км/c. Под действием термальных вод магматические породы утрачивают магнитные свойства. Как правило, магнитная восприимчивость снижается на 2-3 порядка: от (20-40) × $10^{-3}$ СИ в центральной зоне до $\mathrm{n} \times 10^{-5}$ СИ во внешней зоне. В некоторых образцах (C-2, В-6) центральные зоны в значительной степени переработаны, в результате чего их магнитная восприимчивость снижена до (1-4) × 10 ${ }^{-3}$ СИ. Характер изменений магнитной восприимчивости различен: в одних случаях (B-2, A-4) происходит резкое снижение показателя уже в первой зоне, в других (Б-8) - изменение происходит постепенно и резкое снижение наблюдается только во внешней зоне. Основной механизм изменения магнитной восприимчивости пород заключается в растворении ферромагнитных минералов (магнетита, титаномагнетита) кислыми и ультракислыми хлоридно-сульфатными водами, проникающими вглубь обломков по системе микротрещин и пор. Внешняя зона подвергается наиболее динамичному выщелачиванию первичного материала породы с образованием вторичной пористости и трещиноватости вследствие химического и механического воздействия потока гидротерм.

Таким образом, воздействие кислых проточных термальных вод на обломки лав андезидацитового-андезибазальтового состава привело к формированию их зонального строения и ступен- 
(a)
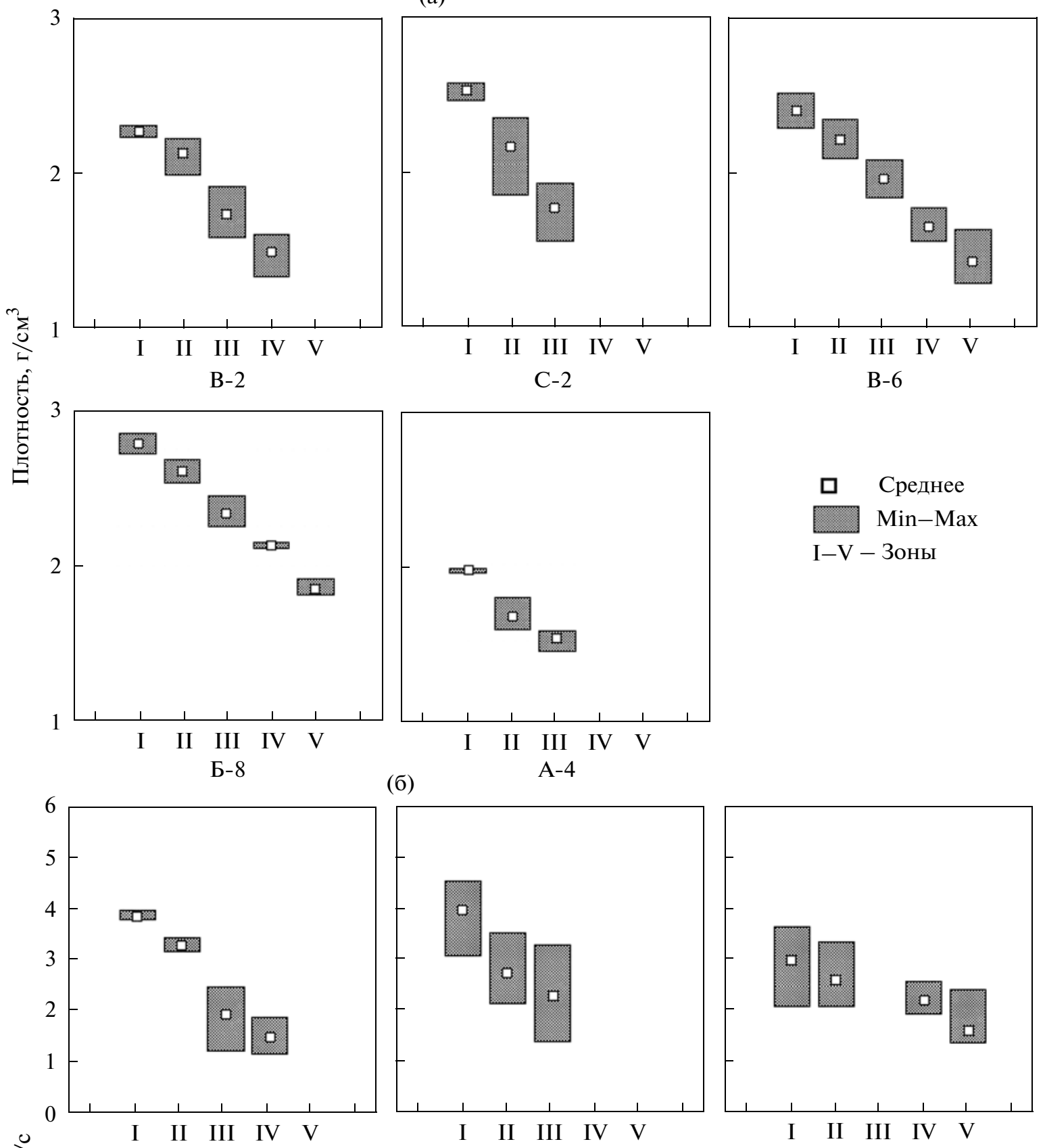

(б)
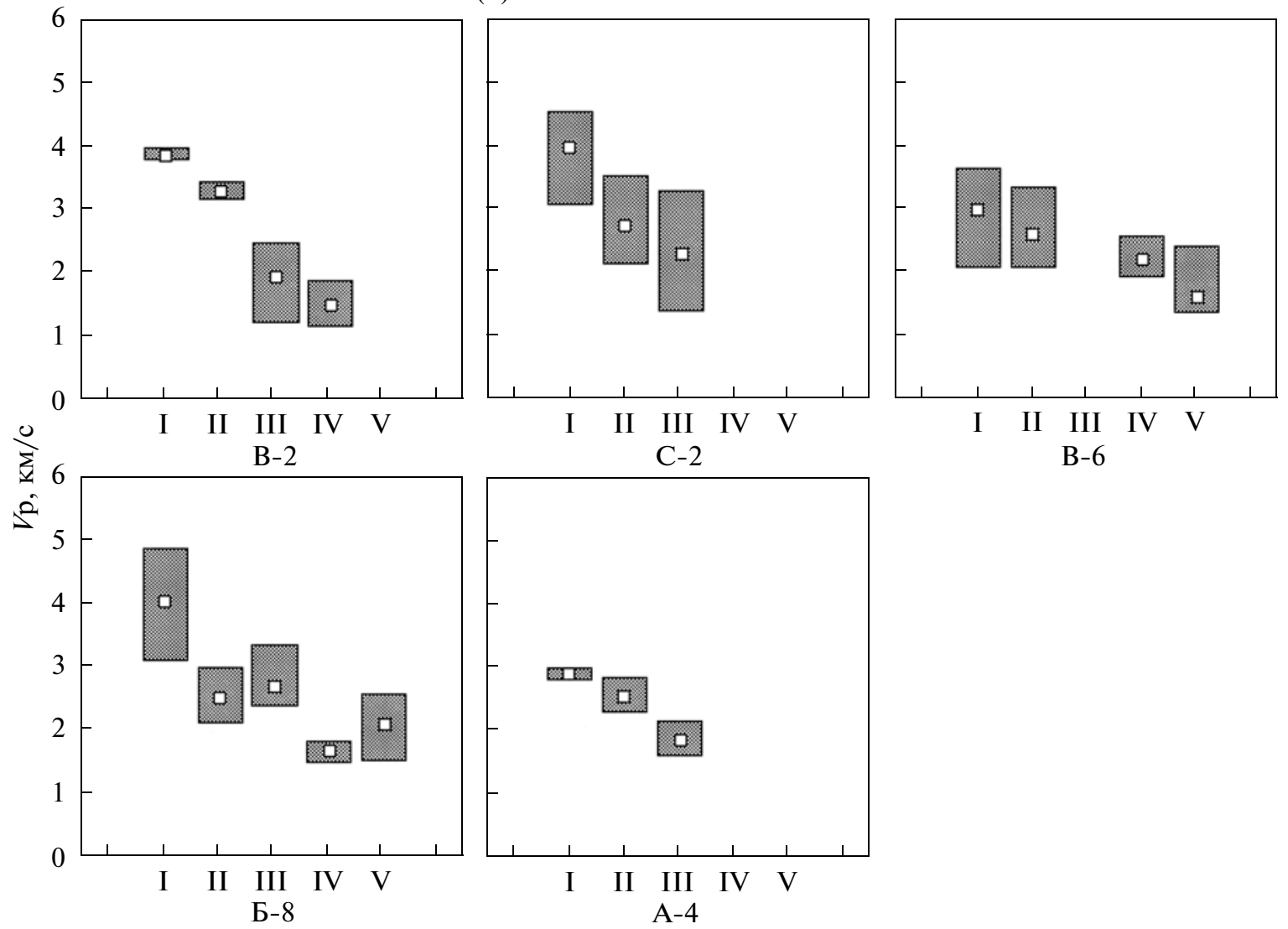
(в)
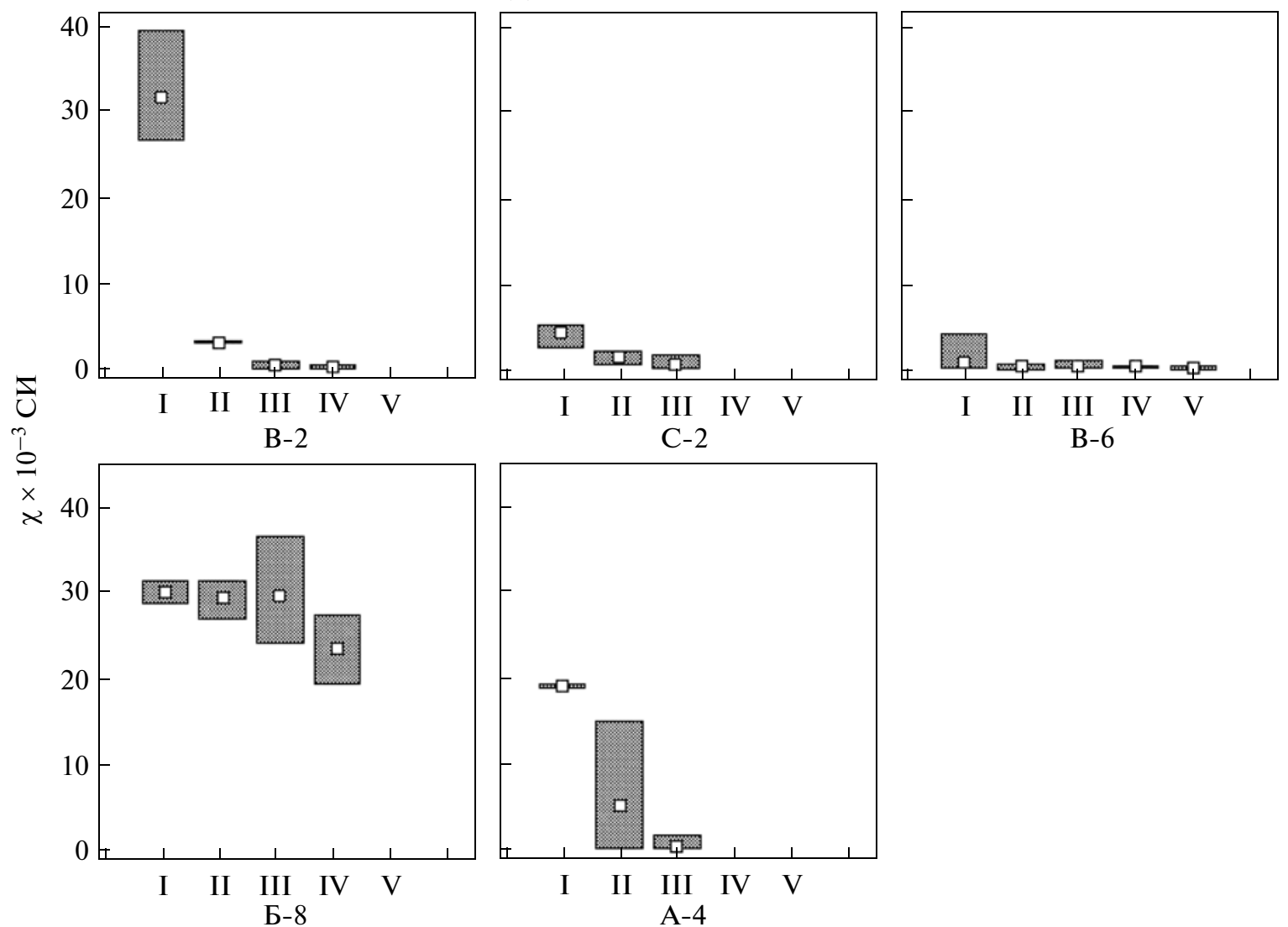

Рис. 5. Изменение петрофизических свойств эффузивов согласно выделенным зонам: a - плотность пород, б - скорость продольных волн, в - магнитная восприимчивость.

чатому изменению состава и свойств. Основным механизмом формирования зон является сернокислотное выщелачивание и метасоматическое замещение основной массы и порфировых вкрапленников минералами кремнезема. На границах зон образуются геохимические барьеры, отражающие изменения физико-химических параметров проточной водной среды, что приводит к осаждению плотного криптокристаллического кремнезема на барьерах. Эти участки могут служить своеобразной (но неполной) изоляцией, затрудняющей переработку внутренних зон. Такие барьеры, вероятно, играют большую роль в эволюции зон и в перераспределении основных компонентов породы, в т.ч. рудных.

Взаимодействие кислых субповерхностных термальных растворов с вмещающими породами с последующим их преобразованием в опалиты отмечается на многих геотермальных системах. Аналогичный процесс, по-видимому, происходит на глубине в зонах восходящего потока термальных вод, насыщенных кислыми вулканическими газами. В частности, такая физико-химическая обстановка (но при более высоких температурах) характерна для апикальных частей малых интрузий габбро-диоритов вулкана Баранского, диоритов Северо-Парамуширской длительноживущей гидротермально-магматической системы, диоритовых порфиритов Кошелевского вулканического массива (Южная Камчатка), над которыми во вмещающих вулканогенно-осадочных породах формируются мощные зоны вторичных кварцитов и геохимические барьеры с эпитермальной рудной минерализацией [Коробов, 1994; Рычагов и др., 2002]. В частности, А.Д. Коробов отмечает, что для гидротермальной системы Баранского на глубине при активном участии галоидов и сернистых газов формируются грейзеноподобные вторичные кварциты, включающие монокварцевую, гранат-кварцевую и мусковит-серицит-кварцевую фации (температуры образования $460-380^{\circ} \mathrm{C}$ ). На сольфатарных полях этой системы образуются серные опалиты, отвечающие по составу вторичным кварцитам и объединяющие опаловую (монокварцевую) и алунит-ярозит-опаловую фации $\left(<200^{\circ} \mathrm{C}\right)$ [Коробов, 1993]. Свободные серная и соляная кислоты вызывают ультракислотное выщелачивание вмещающих пород с образованием 
вторичных кварцитов и монокварцитов на глубине $(\geq 1200$ м) и соответствующих им по составу и условиям образования моноопалитов в зоне гипергенеза геотермальной системы. Эти данные согласуются с полученными нами, согласно которым в системе Баранского на глубине 800-1200 м и на дневной поверхности выделены метасоматиты, характеризующиеся близкими составом, физико-механическими свойствами и условиями образования [Ладыгин, Рычагов, 1995; Рычагов и др., 1993].

\section{ЗАКЛЮЧЕНИЕ}

1. Исследование процесса преобразования валунов и гальки эффузивных пород под действием кислых термальных вод в свободном речном потоке показало, что переработка носит зональный характер. В пределах каждой зоны вещество относительно однородно по составу и свойствам. На границах зон происходит скачкообразное изменение состава породы и петрофизических свойств.

2. От внутренних к внешним зонам образцов пород нарастает степень гидротермально-метасоматической переработки вещества: первичные минералы псевдоморфно замещаются различными низкотемпературными полиморфными модификациями кремнезема. Фронт замещения первичных минералов вторичными новообразованиями составляет доли микрона.

3. Сульфатные и сульфатно-хлоридные термальные воды выщелачивают из породы большинство элементов, за исключением кремния, устойчивого в кислой среде. Вынос элементов сопровождается разуплотнением породы, формированием вторичной пористости и скачкообразным снижением прочностных и деформационных свойств от зоны к зоне.

4. На границах зон часто образуется область уплотнения, связанная с осаждением кремнезема, которая может служить барьером для осаждения некоторых минеральных и рудных соединений.

5. По-видимому, аналогичные, но более высокотемпературные гидротермально-метасоматические процессы происходят в недрах геотермальных систем в зонах восходящего потока термальных вод, насыщенных кислыми вулканическими газами. Поэтому изучение особенностей преобразования вулканогенных пород в проточной кислой среде на дневной поверхности позволяет получать новые данные о природе метасоматической зональности, механизмах и динамике формирования вторичных кварцитов, монокварцитов и опалитов, играющих большую роль в эволюции современных гидротермальных и длительноживущих рудообразующих гидротермально-магматических систем.

Авторы глубоко признательны своим коллегам по экспедиционным работам на острове Итуруп А.Д. Коробову, Н.М. Ульзутуеву, Н.С. Жат- нуеву, Г.П. Королевой, О.П. Гончаренко, С.Ф. Главатских, принимавшим непосредственное участие в полевых маршрутах и в обсуждении основной проблемы, затронутой в данной статье. Мы благодарны также Е.Н. Самарину, В.Г. Шлыкову, А.А. Сасову за проведение большого объема аналитических исследований.

Работа выполнена при финансовой поддержке РФФИ (проект 10-05-00009а, грант № 13-05-00530).

\section{СПИСОК ЛИТЕРАТУРЫ}

Ерощев-Шак B.A. Гидротермальный субповерхностный литогенез Курило-Камчатского региона. М.: Наука, $1992.131 \mathrm{c.}$.

Знаменский В.С., Никитина И.Б. Гидротермы центральной части острова Итуруп (Курильские острова) // Вулканология и сейсмология. 1985. № 5. С. 44-65.

Карпов Г.А. Субповерхностное ртутно-сурьмяно-мышьяковое оруденение и метасоматоз в современных вулканогенных гидротермальных системах // Автореф. дисс ... докт. геол.-мин. наук. Владивосток, 1991. 52 с.

Коржинский Д.С. Очерк метасоматических процессов // Основные проблемы в учении о магматогенных рудных месторождениях. М.: Изд-во АН СССР, 1955. C. 335-456.

Коробов А.Д. Гидротермальные процессы в различных областях вулканизма // Отечественная геология. 1993. № 2. С. 85-92.

Коробов А.Д. Гидротермальный литогенез в областях наземного вулканизма // Автореф. дисс. ... докт. геол.мин. наук. М.: ГИН, 1994. 50 c.

Лабораторные работы по грунтоведению / Под ред. Трофимова В.Т. и Королева В.А. М.: Высшая школа, 2008. 519 c.

Ладыгин В.М., Рычагов С.Н. Гидротермальная система Баранского, о-в Итуруп: блоковая структура и интенсивность гидротермально-метасоматического перерождения пород по петрофизическим данным // Вулканология и сейсмология. 1995. № 5. С. 28-44.

Лебедев Л.М. Минералы современных гидротерм. М.: Наука, 1979. 200 с.

Метасоматизм и метасоматические породы / Под ред. Жарикова В.А. и Русинова В.Л. М.: Научный мир, 1998. 492 c.

Набоко С.И., Карпов Г.А., Розникова Л.П. Гидротермальный метаморфизм пород и минералообразование // Паужетские горячие воды на Камчатке. М.: Наука, 1965. C. 76-118.

Пиелкин В.И. К методике поиска термальных вод в районах современного вулканизма (на примере центральной части о-ва Итуруп) // Всесоюзное совещание по подземным водам Востока СССР. Иркутск-Южно-Сахалинск, 1988. Иркутск: ИЗК СО РАН, 1988. С. 57-58.

Русинов В.Л. Метасоматические процессы в вулканических толщах. М.: Наука, 1989. 213 с.

Рычагов С.Н. Гидротермальная система вулкана Баранского (о. Итуруп): модель геологической структуры // Вулканология и сейсмология. 1993. № 2. С. 59-75.

Рычагов С.Н., Белоусов В.И., Главатских С.Ф. и др. Северо-Парамуширская гидротермально-магматическая 
система: характеристика глубокого геологического разреза и модель современного минералорудообразования в ее недрах // Вулканология и сейсмология. 2002. № 4. С. $3-21$.

Рычагов С.Н., Главатских С.Ф., Гончаренко О.П. и др. Температурная и минералого-геохимическая характеристика геотермального месторождения Океанское (о-в Итуруп) // Геология рудных месторождений. 1993. T. 35. № 5. С. 405-418.

Рычагов С.Н., Соколов В.Н., Чернов М.С. Гидротермальные глины как высокодинамичная коллоидно-дисперсная минералого-геохимическая система // ДАН. 2010. T. 435. № 6. С. 806-809.

Рычагов С.Н., Щегольков Ю.В. Минеральные новообразования на поверхности зерен пирита Нижне-Кошелевской геотермальной аномалии, Южная Камчатка // Руды и металлы. 2011. № 2. С. 52-57.
Фролова Ю.В, Голодковская Г.А., Ладыгин В.М., Рычагов С.Н. О природе инженерно-геологических свойств гидротермально-метасоматических пород Курило-Камчатского региона // Вестник МГУ. 1999. Сер. 4. Геология. № 3. С. 36-42.

Frolova J.V., Ladygin V.M., Rychagov S.N. The Peculiarities of Effusive Leaching under the Action of Acid Thermal Water // Proceeding of the 10th International Symposium on Water-Rock Interaction-WRI-10/Villasimius, Italy, June 10-15, 2001. V. 2. P. 827-830.

Ladygin V.M., Frolova J.V., Rychagov S.N. Formation of composition and petrophysical properties of hydrothermally altered rocks in geothermal reservoir. Proceedings of WGC 2000. Japan, 28 May-10 June, 2000. P. 2695-2699.

Reyes A.G. Petrology of Philippines geothermal systems and the application of alteration mineralogy to their assessment // Volcanology and Geothermal Research. 1990. V. 43. P. 279-309.

\title{
The Alteration of Effusive Rocks Due to Acidic Leaching by Shallow Thermal Waters: The Baranskii Geothermal System, Iturup Island
}

\author{
(C) 2014 r. V. M. Ladygin, Yu. V. Frolova, and S. N. Rychagov \\ Faculty of Geology, Moscow State University, Moscow, 119234 Russia \\ e-mail:skalka@geol.msu.ru \\ Institute of Volcanology and Seismology, Far East Branch, Russian Academy of Sciences, \\ bul'var Piipa 9, Petropavlovsk-Kamchatskii, 683006 Russia \\ e-mail: rychsn@kscnet.ru \\ Received February 20, 2012
}

\begin{abstract}
This paper discusses patterns that are observable in the alteration of effusive rocks that were discharged by Baranskii Volcano (central Iturup Island) under the action of sulfate chloride as well as acidic and ultra-acidic water (in the Kipyashchaya Rechka thermal brook). We acquired data on changes in the chemical and mineralogic composition of the rocks, structural features, porosity, and petrophysical properties. The dynamics of leaching and the leaching phase in a flowing acidic (ultra-acidic) geothermal environment are described. We note that the mechanism that is responsible for hydrogen sulfate leaching of rocks at the ground surface may be largely analogous to the generation of secondary quartzites (mono-quartzites) in the zones of ascending acidic gas flows above small gabbro-diorite and diorite intrusions.
\end{abstract}

